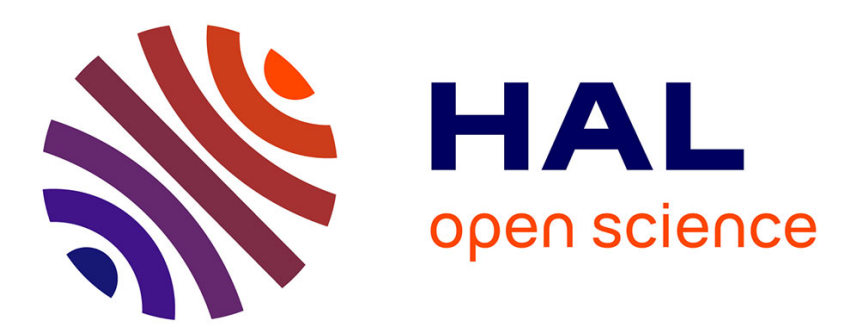

\title{
Structural and DNA binding properties of mycobacterial integration host factor $\mathrm{mIHF}$
}

\author{
Nina T Odermatt, Moreno Lelli, Torsten Herrmann, Luciano A Abriata, \\ Aleksandre Japaridze, Hubert Voilquin, Rajkumar Singh, Jérémie Piton, \\ Lyndon Emsley, Giovanni Dietler, et al.
}

\section{To cite this version:}

Nina T Odermatt, Moreno Lelli, Torsten Herrmann, Luciano A Abriata, Aleksandre Japaridze, et al.. Structural and DNA binding properties of mycobacterial integration host factor mIHF. Journal of Structural Biology, 2020, 209 (3), pp.107434. 10.1016/j.jsb.2019.107434 hal-03094552

\section{HAL Id: hal-03094552 \\ https://hal.science/hal-03094552}

Submitted on 4 Jan 2021

HAL is a multi-disciplinary open access archive for the deposit and dissemination of scientific research documents, whether they are published or not. The documents may come from teaching and research institutions in France or abroad, or from public or private research centers.
L'archive ouverte pluridisciplinaire HAL, est destinée au dépôt et à la diffusion de documents scientifiques de niveau recherche, publiés ou non, émanant des établissements d'enseignement et de recherche français ou étrangers, des laboratoires publics ou privés. 


\section{Structural and DNA Binding Properties of Mycobacterial}

\section{Integration Host Factor mlHF}

3

4

5

6

7

8

9

a. École Polytechnique Fédérale de Lausanne, School of Life Sciences, Station 19, 1015 Lausanne, Switzerland

b. University of Lyon, Institute for Analytical Sciences - Center for High Field NMR, CNRS UMR 5280, ENS Lyon, UCB Lyon 1, France

c. École Polytechnique Fédérale de Lausanne, School of Basic Sciences, Route de la Sorge, 1015 Lausanne, Switzerland

d. École Polytechnique Fédérale de Lausanne, School of Basic Sciences, Av. F.-A. Forel 2, 1015 Lausanne, Switzerland

Corresponding author: Prof. Stewart T. Cole, École Polytechnique Fédérale de Lausanne, Global Health Institute, Station 19, 1015 Lausanne, Switzerland.

Tel. +33145688001

${ }^{1}$ Max Planck Institute for Terrestrial Microbiology, Karl-von-Frisch-Strasse 10, 35043 Marburg, Germany. nina.odermatt@mpi-marburg.mpg.de

2 Department of Chemistry, University of Florence, Via della Lastruccia, 3-13, 50019 Sesto Fiorentino (FI), Italy. moreno.lelli@unifi.it

${ }^{3}$ Centro di Ricerca di Risonanze Magnetiche (CERM), University of Florence, Via Luigi Sacconi 6, 50019 Sesto Fiorentino (FI), Italy. Torsten.Herrmann@ibs.fr

${ }^{4}$ Univ. Grenoble Alpes, CNRS, CEA, IBS, 71 avnue des Marturs, CS 10090, 38044 Grenoble Cedex 9, France. Torsten.Herrmann@ibs.fr

5 luciano.abriata@epfl.ch

6 A.Japaridze@tudelft.nl

7 hubertvoilquin@gmail.com

8 rajkumarbiotech@gmail.com

9 jeremie.piton@gmail.com

10 Iyndon.emsley@epfl.ch

${ }^{11}$ giovanni.dietler@epfl.ch

12 Institut Pasteur, 25-28 rue du Docteur Roux, 75724 Paris Cedex 15, France 
Abstract

In bacteria, nucleoid associated proteins (NAPs) take part in active chromosome organization by supercoil management, three-dimensional DNA looping and direct transcriptional control. Mycobacterial integration host factor (mIHF, rv1388) is a NAP restricted to Actinobacteria and essential for survival of the human pathogen Mycobacterium tuberculosis. We show in vitro that DNA binding by mIHF strongly stabilizes the protein and increases its melting temperature. The structure obtained by Nuclear Magnetic Resonance (NMR) spectroscopy characterizes mIHF as a globular protein with a protruding alpha helix and a disordered $\mathrm{N}$ terminus, similar to Streptomyces coelicolor IHF (sIHF). NMR revealed no residues of high flexibility, suggesting that mIHF is a rigid protein overall that does not undergo structural rearrangements. We show that mIHF only binds to double stranded DNA in solution, through two DNA binding sites (DBSs) similar to those identified in the $x$-ray structure of slHF. According to Atomic Force Microscopy, mIHF is able to introduce left-handed loops of ca. $100 \mathrm{~nm}$ size ( $300 \mathrm{bp})$ in supercoiled cosmids, thereby unwinding and relaxing the DNA.

\section{Highlights}

- The structure of mIHF was solved by solution NMR spectroscopy

- $\quad$ mIHF is an alpha-helical protein with two DNA-binding sites

- mIHF introduces left-handed loops into DNA

- DNA unwinds and re-compacts in a mIHF-level dependent manner

\section{Keywords}

Mycobacterial Integration Host Factor, mIHF, Nucleoid Associated Protein, DNA binding, NMR structural determination, atomic force microscopy

\section{Abbreviations}

mIHF, mycobacterial Integration Host Factor; DBS, DNA-binding site; dsDNA, double stranded DNA; NAP, nucleoid associated protein; ssDNA, single stranded DNA 


\section{Introduction}

Tuberculosis, caused by Mycobacterium tuberculosis, is the leading cause of death by a single infectious agent, claiming over 1.5 million lives each year (WHO, 2016). The pathogen mainly causes lung infections (Farer et al., 1979) that are hard to diagnose, difficult to treat and can lead to death when undetected (Zumla et al., 2013). M. tuberculosis can enter a dormant phase (Boshoff and Barry, 2005), characterized by phenotypic drug resistance (Gomez and McKinney, 2004) and has evolved a sophisticated virulence strategy employing type VII secretion systems known as ESX-1 to ESX-5 (Gröschel et al., 2016). Control of virulence factor expression is crucial and has to be carefully adapted to active growth or the latent phase (Zondervan et al., 2018). Transcription is controlled over interlayered levels involving the DNA supercoiling state and by local transcription factors, such as repressors and activators, sigma factors and nucleoid associated proteins (NAPs) (Balleza et al., 2009).

NAPs are small, highly abundant proteins in bacteria with hundreds of binding sites on the chromosome. Their ability to bridge DNA, assisted by supercoiling and macromolecular crowding, leads to compaction of the chromosome (Luijsterburg et al., 2006) and its organization into $1 \mathrm{Mbp}$ macrodomains (Song and Loparo, 2015). In addition to their architectural role, NAPs act as global gene regulators, often involved in induction of virulence expression and genetic adaptation to environmental cues (Dorman, 2004). In E. coli, at least 12 NAPs have been identified that regulate a vast number of genes (Dillon and Dorman, 2010). Although M. tuberculosis is exposed to different stresses during host entry and the accompanying immune response (Manganelli et al., 2004), and can also enter a nonreplicating state, NAPs seem to be underrepresented in this bacterium. To date, only four proteins were confirmed to act as NAPs; Lsr2, HupB, EspR and mIHF. Lsr2 protects $M$. tuberculosis from reactive oxygen species (Colangeli et al., 2009), and acts as a dimer (Summers et al., 2012) in repressing gene expression (Gordon et al., 2010). HupB is the only conserved NAP and shows sequence similarity to HU of Gram-negative bacteria. HupB is involved in iron homeostasis, cell wall synthesis and adhesion (Pandey et al., 2014). EspR is essential for the expression of the ESX-1 virulence factors and several other virulence associated genes besides (Blasco et al., 2012). The mycobacterial integration host factor, mIHF, was shown to be essential for bacterial survival and regulates genes involved in lipid metabolism, metabolic pathways, translation and virulence (Odermatt et al., 2018). 
82 Most NAPs act as dimers, with each monomer binding to a distinct DNA locus and bringing these loci together upon dimerization, as exemplified by EspR (Blasco et al., 2011), Lsr2

84 (Summers et al., 2012) or HupB (Bhowmick et al., 2014) in M. tuberculosis. On the contrary, 85 the mIHF homologue from Streptomyces coelicolor, slHF, has two separate DNA-binding sites (DBS) and was proposed to bind DNA as a monomer (Swiercz et al., 2013). mIHF was shown

87 to bind and bend DNA non-specifically (Mishra et al., 2013), but the exact DNA-binding 88 mechanism of mIHF and its structure are unknown. Here, we complement the genetic analysis of mIHF (Odermatt et al., 2018) by providing structural insights into its biological

90 function. We determined the solution state structure of mIHF and measured its dynamics by 91 Nuclear Magnetic Resonance (NMR) spectroscopy, and studied its DNA binding properties by NMR, Isothermal Titration Calorimetry (ITC), and Atomic Force Microscopy (AFM). 


\section{Methods}

\subsection{Sequence analysis and alignment}

Amino acid sequences were obtained from NCBI, aligned with T-Coffee (Notredame et al., 2000) and visualized with BioEdit (Thomas A. Hall, 1999). Secondary structure was predicted by PSIPRED (Jones et al., 2017).

\subsection{Cloning, expression and purification of mIHF}

Oligonucleotides were synthesized by MICROSYNTH (Switzerland). Primers mihF-exp-F and mihf-exp-R (all primers are listed in Table S1) were used to PCR-amplify the mihF gene beginning at the translational start site. Restriction sites $\mathrm{Ndel}$ and $\mathrm{BamHI}$ were included in the primers to clone the resulting fragment into $\mathrm{PET} 28 \mathrm{a}$ vector to give the expression vector pNO72 producing N-terminally 6x His-tagged mIHF protein. Recombinant His-tagged protein was expressed by growing E. coli BL21 DE3 (ThermoFisher) cells transformed with pNO72 in Luria-Bertani (LB) broth in the presence of $50 \mu \mathrm{g} \mathrm{ml}^{-1}$ kanamycin. Protein expression was induced at an $\mathrm{OD}_{600}=0.6$ with $500 \mu \mathrm{M}$ IPTG overnight at $16^{\circ} \mathrm{C}$ with constant shaking at 180 rpm. Cells were harvested by centrifugation and stored at $-80^{\circ} \mathrm{C}$ until further processing. The pellet was thawed in lysis buffer $(50 \mathrm{mM}$ Tris- $\mathrm{HCl}$ pH 7.5, $500 \mathrm{mM} \mathrm{NaCl}, 1 \mathrm{mM}$ Imidazole, $10 \%(\mathrm{w} / \mathrm{v})$ glycerol and $1 \%$ TWEEN 20) supplemented with 1 tablet COMPLETE mini protease inhibitor (Roche) and $10 \mu \mathrm{l}$ DNase I (Roche) and lysed in a cell disrupter (EmulsiFlex, Avestin, Canada). Insoluble debris was removed after centrifugation and supernatant was loaded on a His-trap column pre-equilibrated with buffer $\mathrm{A}(500 \mathrm{mM} \mathrm{NaCl}, 50 \mathrm{mM}$ Tris- $\mathrm{HCl} \mathrm{pH}$ 7.5). Increasing concentrations of buffer $B(500 \mathrm{mM} \mathrm{NaCl}, 50 \mathrm{mM}$ Tris- $\mathrm{HCl} \mathrm{pH}$ 7.5, $500 \mathrm{mM}$ Imidazol) eluted the protein from the column and fractions were visualized by COOMASSIE blue staining of a sodium dodecyl sulphate (SDS) gel (NuPAGE 4 - 12\% Bis-Tris Gel, INVITROGEN). Pooled fractions containing mIHF were dialyzed into Tris-buffer (150 mM NaCl, $50 \mathrm{mM}$ Tris- $\mathrm{HCl} \mathrm{pH} \mathrm{7.5)} \mathrm{overnight} \mathrm{at} 4^{\circ} \mathrm{C}$. To remove the His-tag, $500 \mu \mathrm{l}$ thrombin (Sigma) was added to the protein before dialysis. The cut mIHF protein was subsequently purified by passage over Ni-NTA Agarose (Machery-Nagel) and Benzamidine Sepharose (GE Healthcare) to remove uncut protein, His-tags and thrombin. A size-selection purification step was applied to remove unfolded protein and increase sample purity. mIHF was passed over a HiLoad 16/600 column and fractions were pooled and concentrated in centrifugal filters 
123 (Ultracel, Amicon) with $3 \mathrm{kDa}$ cut-off. Purified mIHF was stored at $-80^{\circ} \mathrm{C}$ in small aliquots until further use. Concentration of mIHF was measured by Qubit (INVITROGEN).

125 Primers mihF-R90E-F and mihF-R90E-R were used in the QuickChange II Site-Directed Mutagenesis kit (Agilent) as recommended by the manufacturer. The single amino acid mutation R90E in pNO72 gave rise to pNO84.

128 For the production of isotope labelled $\mathrm{mIHF}\left({ }^{15} \mathrm{~N}\right.$ - and ${ }^{13} \mathrm{C}$-ammonium chloride and D-glucose from Cambridge Isotope Laboratories, USA), the exponentially growing culture was resuspended in minimal medium containing $25 \mathrm{mM} \mathrm{KH}_{2} \mathrm{PO}_{4}, 50 \mathrm{mM} \mathrm{Na}_{2} \mathrm{HPO}_{4} \cdot 2 \mathrm{H}_{2} \mathrm{O}, 1 \mathrm{~g} \mathrm{I}^{-1}$ ${ }^{15} \mathrm{~N}$-labelled ammonium chloride, $10 \mathrm{mM} \mathrm{NaCl}, 0.2 \mathrm{mM} \mathrm{CaCl}, 1 \mathrm{mM} \mathrm{MgSO}{ }_{4}, 50 \mu \mathrm{M}$ iron solution, $10 \mathrm{ml}$ trace metal solution and $3 \mathrm{~g} \mathrm{I}^{-1}{ }^{13} \mathrm{C}$ labelled glucose. $1000 \mathrm{x}$ iron solution contained $100 \mu \mathrm{M}$ citric acid and $50 \mu \mathrm{M} \mathrm{FeCl}_{3} .100 \times$ trace metal solution contained $68.2 \mu \mathrm{M}$ $\mathrm{MnCl}_{2} \cdot 4 \mathrm{H}_{2} \mathrm{O}, 3.7 \mu \mathrm{M} \mathrm{ZnSO}_{4} \cdot 7 \mathrm{H}_{2} \mathrm{O}, 0.4 \mu \mathrm{M} \mathrm{CoCl} 2 \cdot 6 \mathrm{H}_{2} \mathrm{O}, 0.6 \mu \mathrm{M} \mathrm{CuCl}_{2} \cdot 2 \mathrm{H}_{2} \mathrm{O}, 1.6 \mu \mathrm{M}$ $\mathrm{H}_{3} \mathrm{BO}_{3}, 2.1 \mu \mathrm{M} \mathrm{NiCl} 2 \cdot 6 \mathrm{H}_{2} \mathrm{O}, 2.1 \mu \mathrm{M} \mathrm{Na}_{2} \mathrm{MoO}_{4} \cdot 2 \mathrm{H}_{2} \mathrm{O}, 1.9 \mu \mathrm{M} \mathrm{Na}_{2} \mathrm{SeO}_{3} \cdot 5 \mathrm{H}_{2} \mathrm{O}$. E. coli was grown overnight in minimal medium at $16^{\circ} \mathrm{C}$ and protein was purified as described above.

Due to the remainder of the His-tag (GSHM), the actual mIHF protein starts with amino acid 5 (underlined). The sequence of the protein used throughout this investigation is thus: GSHMVALPQLTDEQRAAALEKAAAARRARAELKDRLKRGGTNLTQVLKDAESDEVLGKMKVSALLEALP KVGKVKAQEIMTELEIAPTRRLRGLGDRQRKALLEKFGSA.

\subsection{Circular dichroism (CD) measurement}

142 Circular dichroism of mIHF was measured at a concentration of $10-20 \mu \mathrm{M}$ protein in a quartz cuvette of $1 \mathrm{~mm}$ path length and analysed using a Jasco J-815 CD spectrometer. Data were converted to mean residual ellipticity and corrected for difference in concentration (Greenfield, 2007). Far UV (195 - $250 \mathrm{~nm})$ was used for protein, and near UV (250 - $340 \mathrm{~nm})$ for DNA absorbance. Thermal unfolding was monitored over the whole spectra. Molar ellipticity changes at $222 \mathrm{~nm}$ were used to fit a sigmoidal model and calculate the melting temperature (GraphPad Prism). DNA titration was carried out at $20^{\circ} \mathrm{C}$ with $0,0.003,0.006$, $0.340,0.500$ and 0.700 equivalents of DNA. A 40 bp dsDNA oligonucleotide $\left(5^{\prime}\right.$ CTGGAGGAGCTGGCAGCAGCGTTTCCGGGTGATGGCTGGT - 3') was used. As mIHF does not contain amino acids that absorb at $280 \mathrm{~nm}$, the signal was undisturbed in the transition between near and far UV. 


\subsection{Gel retardation assay}

155

156

157

158

159

160

161

162

163

$100 \mathrm{ng}$ linear DNA was incubated with increasing amounts of recombinant mIHF (1 pmol - 2 nmol) and $\mathrm{mIHF}$ R90E $(0.1 \mathrm{nmol}-2 \mathrm{nmol})$ for $10 \mathrm{~min}$ at room temperature and electrophoresed on a $0.75 \%$ agarose gel in $0.5 x$ TBS $(25 \mathrm{mM}$ Tris- $\mathrm{HCl}$ pH 7.5, $50 \mathrm{mM} \mathrm{NaCl})$. Post-run staining was performed with GelRed (Biotium) for $20 \mathrm{~min}$ at a 1:10'000 ratio of GelRed to $0.5 x$ TBS.

\subsection{Nuclear Magnetic Resonance (NMR) spectroscopy and solution structure}

\section{determination}

NMR measurements for protein assignment and structure determination were carried out on $1.34 \mathrm{mM}$ uniformly ${ }^{13} \mathrm{C}$ - and ${ }^{15} \mathrm{~N}$-labelled mIHF samples in $100 \mu \mathrm{l}$, using Shigemi NMR tubes. Protein solution was prepared in $90 \% \mathrm{H}_{2} \mathrm{O}(50 \mathrm{mM}$ phosphate buffer $\mathrm{pH}$ 7.5, $100 \mathrm{mM}$ $\mathrm{NaCl}$ ) and $10 \%{ }^{2} \mathrm{H}_{2} \mathrm{O} .0 .2 \%$ sodium azide was added to prevent sample degradation. The NMR spectra were acquired at $14.1 \mathrm{~T}, 18.8 \mathrm{~T}$ and $23.5 \mathrm{~T}(600.55,800.13$ and $1000.30 \mathrm{MHz}$ of proton Larmor frequency, respectively) on Bruker Avance III spectrometers, all equipped with a cryogenic cooled probehead. The experiments for determining the ${ }^{1} \mathrm{H},{ }^{13} \mathrm{C}$ and ${ }^{15} \mathrm{~N}$ protein backbone resonance assignment were performed at $14.1 \mathrm{~T}$, using the standard JUNIO protocol (Serrano et al., 2012) automated assignment APSY routine. Standard CBCACONH (Hiller et al., 2008), HACACONH (Fiorito et al., 2006), and HACANH (Hiller et al., 2005) APSY experiments were used; the $\pi / 2$ hard pulses were $11.18 \mu \mathrm{s} 14.45 \mu \mathrm{s}$ and $37.2 \mu \mathrm{s}$ for ${ }^{1} \mathrm{H},{ }^{13} \mathrm{C}$ and ${ }^{15} \mathrm{~N}$, respectively. The number of projections acquired were 56,56 , and 41 with 16, 8, and 8 scans for CBCACONH, HACACONH, and HACANH, respectively, and with a direct acquisition time of $91.7 \mathrm{~ms}$ and a recycle delay of $0.9 \mathrm{~s}$. The ${ }^{1} \mathrm{H}_{-}{ }^{15} \mathrm{~N} 3 \mathrm{D}$ and ${ }^{1} \mathrm{H}_{-}{ }^{13} \mathrm{C} 3 \mathrm{D}$ HSQC NOESY spectra used to obtain side-chain resonance assignments and structural restraints for the solution structural determination were performed at $18.8 \mathrm{~T}$ and $288 \mathrm{~K}$ using standard NMR sequences. The $\pi / 2$ hard pulses were $10.52 \mu s 13.6 \mu$ s and $35.0 \mu$ s for ${ }^{1} \mathrm{H},{ }^{13} \mathrm{C}$ and ${ }^{15} \mathrm{~N}$, respectively. The mixing times were $100 \mathrm{~ms}$ and $120 \mathrm{~ms}$ for ${ }^{1} \mathrm{H}-{ }^{15} \mathrm{~N}$ 3D and ${ }^{1} \mathrm{H}-{ }^{13} \mathrm{C}$ 3D HSQC NOESY, respectively. Up to $1536 \times 72 \times 100$ complex points were acquired for direct ${ }^{1} \mathrm{H}$, indirect ${ }^{15} \mathrm{~N}$ and ${ }^{1} \mathrm{H}$ dimensions, respectively; for ${ }^{1} \mathrm{H}-{ }^{13} \mathrm{C} 3 \mathrm{D}$ HSQC NOESY $1088 \mathrm{x}$ $80 \times 90$ complex points were acquired for direct ${ }^{1} \mathrm{H}$, indirect ${ }^{13} \mathrm{C}$ and ${ }^{1} \mathrm{H}$ dimensions, respectively. The number of scans were 8 , with a direct acquisition time of $84.86 \mathrm{~ms}$ and a 
recycle delay of 1.20 s. Data were processed with 1024 x $128 \times 256$ complex points matrix and square cosine window functions.

The analysis of the APSY experiments was performed with the software UNIO-MATCH for automated backbone resonance assignment (Volk et al., 2008) and UNIO-ATNOS/ASCAN (Fiorito et al., 2008) for automated side-chain chemical shift assignment. The input for automated NOESY peak picking and NOE assignments with UNIO-ATNOS/CANDID (Herrmann et al., 2002a, 2002b) consisted of the UNIO-MATCH chemical shift assignments for the polypeptide backbone, the UNIO-ATNOS/ASCAN output of side-chain chemical shift assignments, and the NOESY datasets. Table 1 reports NMR structural statistics from NOE assignment and structure calculation using UNIO-ATNOS/CANDID.

\subsection{DNA titration experiments monitored by NMR}

The ${ }^{15} \mathrm{~N}$-labeled protein was prepared at $200 \mu \mathrm{M}$ in $50 \mathrm{mM}$ phosphate buffer $\mathrm{pH} 7.5,100$ $\mathrm{mM} \mathrm{NaCl}$, with $10 \%{ }^{2} \mathrm{H}_{2} \mathrm{O}$. Titration of this sample with dsDNA (5'-AGCTCGTCAACGCCTT-3', 5 mM stock solution, purchased from MICROSYNTH) was monitored through ${ }^{1} \mathrm{H},{ }^{15} \mathrm{~N}$ HSQC spectra collected at $298 \mathrm{~K}$ on an AVANCEII-800 MHz spectrometer equipped with a CPTC ${ }^{1} \mathrm{H},{ }^{13} \mathrm{C},{ }^{15} \mathrm{~N} 5 \mathrm{~mm}$ cryoprobe. The HSQC spectra were collected with 128 increments in the ${ }^{15} \mathrm{~N}$ dimension. Since broadening was observed for most crosspeaks along the titration, the number of scans was increased throughout the titration as required to keep a workable signal-to-noise ratio (from 8 scans without DNA to 64 scans at 2.2 equivalents of added DNA).

All data for titrations were acquired and processed with a Bruker TOPSPIN 2.0 instrument and analysed with NMRFAM-SPARKY. For data analysis, the backbone ${ }^{1} \mathrm{H}$ and ${ }^{15} \mathrm{~N}$ assignments derived from the automatic structure calculation procedure were first verified against 3D CBCANH and $\mathrm{HN}(\mathrm{CA}) \mathrm{CO}$ spectra. All assignments except that for Arg27 were confirmed, while assignments for Gly40, Arg92 and Asp96 were also retrieved. After this procedure the only non-proline residues missing $\mathrm{H}, \mathrm{N}$ assignments are Gly1 through Met4, Leu19, Arg27 through Ala30 and Arg97. The final table of backbone $\mathrm{H}, \mathrm{N}$ assignments is given in Fig. S1, CBCANH spectra in Fig. S2.

Chemical shift perturbations (CSP) were calculated from weighed differences in ${ }^{1} \mathrm{H}$ and ${ }^{15} \mathrm{~N}$ chemical shifts $(\Delta \delta H$ and $\Delta \delta N$, (Williamson, 2013)) as: 


$$
C S P=\sqrt{\frac{(\Delta \delta H)^{2}+(\Delta \delta N / 5)^{2}}{2}}
$$

\section{$2.7{ }^{15} \mathrm{~N}$-Relaxation data}

The backbone dynamics of mIHF was investigated through ${ }^{15} \mathrm{~N}$-relaxation measurements, acquired on the same sample described above for structure determination at $298 \mathrm{~K}$, corrected for the different temperature. Standard experiments (Cavanagh et al., 2007) were used to measure the longitudinal and transverse ${ }^{15} \mathrm{~N}$ relaxation times $\left({ }^{1} \mathrm{H}^{15}{ }^{15} \mathrm{HSQC} \mathrm{T}_{1}\right.$ and ${ }^{1} \mathrm{H}_{-}{ }^{15} \mathrm{~N}$ HSQC T ) (Kay et al., 1992) and the $\left\{{ }^{1} \mathrm{H}\right\}-{ }^{15} \mathrm{~N}$ NOE HSQC at $23.5 \mathrm{~T}\left(1.0 \mathrm{GHz}\right.$ of ${ }^{1} \mathrm{H}$ Larmor frequency). For these experiments, the $\pi / 2$ hard pulses were $11.93 \mu \mathrm{s} 13.75 \mu \mathrm{s}$ and $26.5 \mu \mathrm{s}$ for ${ }^{1} \mathrm{H},{ }^{13} \mathrm{C}$ and ${ }^{15} \mathrm{~N}$, respectively. The build-up times for the ${ }^{15} \mathrm{~N} \mathrm{~T}_{1}$ were $0.010 \mathrm{~s}, 0.010 \mathrm{~s}$, $0.100 \mathrm{~s}, 0.300 \mathrm{~s}, 0.500 \mathrm{~s}, 0.700 \mathrm{~s}, 1.00 \mathrm{~s}, 1.30 \mathrm{~s}, 1.60 \mathrm{~s}, 1.60 \mathrm{~s}$, with two experiments acquired twice. To measure ${ }^{15} \mathrm{~N} \mathrm{~T}_{2}$ a CPMG sequence was used with a $\tau-\tau-\tau$ sequence of $450 \mu$ s for $\tau$ delay and $160 \mu \mathrm{s}$ for the $\pi$-pulse. The CMPG build-up times were $17 \mathrm{~ms}, 34 \mathrm{~ms}, 51 \mathrm{~ms}, 68 \mathrm{~ms}$, $68 \mathrm{~ms}, 102 \mathrm{~ms}, 136 \mathrm{~ms}, 170 \mathrm{~ms}, 204 \mathrm{~ms}$ with one experiment acquired twice. For each buildup point the number of scans were 32 with $1.50 \mathrm{~s}$ of recycle delay for the ${ }^{1} \mathrm{H}^{15}{ }^{15} \mathrm{HSQC} \mathrm{T}$, and $2.50 \mathrm{~s}$ of recycle delay for the ${ }^{1} \mathrm{H}^{-15} \mathrm{~N} \mathrm{HSQC} \mathrm{T}_{2}$ to allow for the probe duty cycle. For the $\left\{{ }^{1} \mathrm{H}\right\}-{ }^{15} \mathrm{~N}$ NOE HSQC 64 scans were acquired for each experiment, with a saturation time of 6.0 s. Each point in the HSQC plane relaxation data was processed with a $2048 \times 512$ complex points matrix and square cosine windows function for both direct and indirect dimensions. Relaxation data were analysed with the Protein Dynamics Center 2.4.6 (2016 Nov/14) software provided by BRUKER BIOSPIN.

\subsection{Isothermal titration calorimetry}

ITC experiments were performed using a Malvern MicroCal PEAQ-ITC calorimeter (Malvern Instruments) at $25^{\circ} \mathrm{C}$ with 19 injections of substrate addition. ITC cells were loaded with 300 $\mu \mathrm{l}$ of 5-10 $\mu \mathrm{M}$ mIHF in buffer $\mathrm{A}(10 \mathrm{mM}$ Tris, $\mathrm{pH}$ 8.0, $50 \mathrm{mM} \mathrm{NaCl})$. Different length DNA oligonucleotides were used for binding measurements: 7bp ssDNA (3'-CTCACGC-5', 100-500 $\mu \mathrm{M}), 7 \mathrm{bp}$ dsDNA (100-250 $\mu \mathrm{M}), 16 \mathrm{bp}$ ssDNA (5'-AGCTCGTCAACGCCTT-3', 100-250 $\mu \mathrm{M}$ ), 16bp dsDNA (100-500 $\mu \mathrm{M})$, 40bp ssDNA (5'-CTGGAGGAGCTGGCAGCAGCGTTTCCGGGTGATGGCTGGT3', 100-250 $\mu \mathrm{M})$, and 40bp dsDNA (100-500 $\mu \mathrm{M})$. Data were analysed using Malvern PEAQITC analysis software provided by Malvern instruments. 


\subsection{Atomic force microscopy}

The mihF gene and promoter region were obtained by amplification with primers mihFprom-F and mihF-prom-R. Cloning of the product into pTOPO (ThermoFisher) gave rise to pNO75. pNO75 was cut with Spel and BamHI and the resulting linear fragment was purified with the PCR purification kit (Sigma-Aldrich). 195 cosmid DNA consists of a $42.6 \mathrm{~kb}$ region, coordinates 4,292,000 -4,326,000 of the M. tuberculosis chromosome, cloned into pYUB412 and amplified in E. coli (Bange et al., 1999). Cosmid DNA was extracted using a Midi Prep kit (Promega) and eluted in TE buffer (10 mM Tris, 1 mM EDTA).

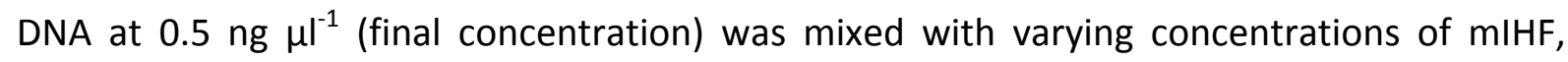
brought to a final volume of $20 \mu \mathrm{l}$ in buffer II $(5 \mathrm{mM} \mathrm{MgCl}, 5 \mathrm{mM}$ Tris- $\mathrm{HCl} \mathrm{pH} \mathrm{7.5,50} \mathrm{mM}$ $\mathrm{NaCl}$, for linear fragment) or in ultrapure water (for cosmid 195). The mixture was deposited on freshly cleaved mica and incubated for $5 \mathrm{~min}$ at $25^{\circ} \mathrm{C}$. For experiments with 195 cosmid, the mica surface was functionalized with APTES in a separate step prior to DNA deposition as described previously (Japaridze et al., 2016). AFM images were collected using a MultiMode SPM with a Nanoscope III controller (VEECO Instruments, Santa Barbara, CA, USA) operated in tapping-mode in air. The AFM cantilevers had a spring constant of $5 \mathrm{~N} / \mathrm{m}$ (Bruker cantilevers, TAP150A) with resonance frequencies ranging between 120 and $160 \mathrm{kHz}$. All AFM images consist of $512 \times 512$ pixels with scan frequency $\leq 1 \mathrm{~Hz}$. Each experiment was performed at least in duplicate and AFM images were obtained at several separate mica locations. Only DNA complexes that were completely visible in an AFM image were considered for statistical analysis. Images were simply flattened using the GWYDDION software (Version 2.22), and no further image processing was carried out (Nečas and Klapetek, 2012).

DNA molecules were traced using DNA TRACE software previously described (Mikhaylov et al., 2013). Based on the statistics of tens-to-hundreds of individual molecules the contour length and the radius of gyration were calculated by the software.

\subsection{LC-MS/MS}

Bands of interest were excised from SDS-PAGE gels and in-gel digested with trypsin or chymotrypsin. After gel extraction, samples were dried by vacuum centrifugation and analysed by LC-MS/MS. Peptides were separated on a Dionex Ultimate 3000nano UPLC system coupled in-line to a high-resolution mass spectrometer (ThermoFisher Scientific). A pre-column (ACCLAIM PEPMAP C18 Trap) was used to capture the samples and separation was 
273 performed over a 90-min gradient using a capillary column (ACCLAIM PEPMAP C18 RSLC) at 250

$274 \mathrm{nl} \mathrm{min}{ }^{-1}$. Positive data-dependent acquisition mode was used and precursor peptides with 275 charge $>2$ were fragmented. Database search was performed with Proteome Discoverer 1.4 276 on Mascot, Sequest and MS-Amanda against Tuberculist R27 database (Lew et al., 2011). 277 Met oxidation, Ser-Thr-Tyr phosphorylation and peptide $\mathrm{N}$-acetylation were set as variable 278 modifications while Cys carbamidomethylation was set as fixed modification. Scaffold 4.75 279 was used for data inspection.

\subsection{Accession ID}

281 The atomic coordinates and structure of mIHF (Rv1388) have been deposited in the Protein 282 Data Bank under the accession number xxxx. 


\section{1 mIHF DNA binding domain prediction and mutant generation}

286 The 105-amino acid mIHF protein has a calculated molecular weight of $11.5 \mathrm{kDa}$ and contains no tryptophan, tyrosine or cysteine residues, rendering this protein much harder to detect by UV-Vis spectrophotometry. Amino acid sequence alignments (Fig. 1) show that mIHF is highly conserved among Actinobacteria. Conversely, mIHF does not share any sequence similarity with its orthologues from Gram-negative bacteria.

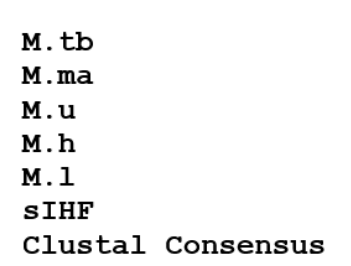

M.tb
M.ma
M.u
M.h
M.l
sIHF
Clustal Consensus
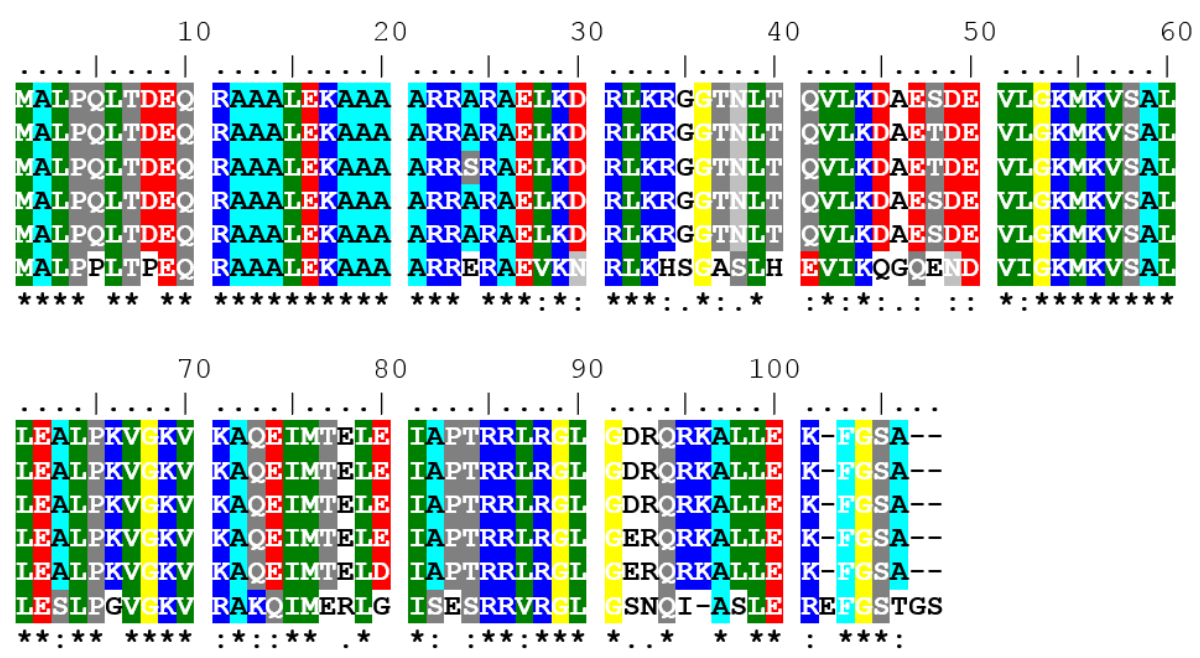

291

292

293

294

295

296

297

298

299

300

301

302

303

304

305

306

Fig. 1. Amino acid sequence alignment of IHF proteins. Amino acids are similarity coded using the BLOSUM62 matrix at $80 \%$ cutoff. mIHF from M. tuberculosis (M.tb) is aligned with protein sequences from M. marinum (M.ma), M. ulcerans (M.u), M. haemophilum (M.h), M. leprae (M.I) and slHF from S. coelicolor (sIHF, SCO1480).

Secondary structure prediction revealed mIHF to be an alpha-helical protein, with the first helix (residues 8 - 34) predicted to form a coiled coil ((Lupas et al., 1991), Fig. S3). slHF contains a helix-two turns-helix $(\mathrm{H} 2 \mathrm{TH})$ motif, where the two turns between the helices contact DNA at DBS-I of the protein. The second DBS lies on the opposite side of the protein, in a turn connecting two helices (Swiercz et al., 2013) and the proposed DNA binding mode suggests a new category of NAPs, characterized by two distinct DNA binding domains in the same protein rather than by dimerization of two proteins with one DBS each. SIHF is thus unique and not related to other NAPs like IHF or H-NS from E. coli or Lsr2 from $M$. tuberculosis (Swiercz et al., 2013).

Alignment of mIHF with sIHF showed high homology levels between the two sequences, with $62 \%$ identity and $79 \%$ similarity ((Altschul SF et al., 1990), BLOSUM62 matrix). These data suggested that the two proteins might have a very similar structure. We therefore exploited 
the sIHF structure with the predicted DBSs (Swiercz et al., 2013) to identify the putative DBSs of mIHF. Overall, both domains were conserved but several interesting differences between slHF and mIHF were noticed. For instance, positions G67 and G80 in slHF were occupied by the positively charged lysine and the negatively charged glutamic acid residues, respectively, in mIHF. These changes might reflect the adaptation to specific DNA binding patterns in the respective genomes or modify sequence specificity. Furthermore, several positively charged arginine residues are present in the mIHF and sIHF DBS and are presumably responsible for the direct contact with the negatively charged DNA backbone. We chose R90, R92 and G93 conserved in both proteins, as targets of site-directed mutagenesis to investigate the DNA binding properties of the mutant proteins. Arginine was mutated to glutamic acid (R90E, R92E), and glycine to tryptophan (G93W). The mutant proteins containing R92E or G93W were not stable after purification, while mIHF R90E was as stable as mIHF wild type (wt) and therefore used for future experiments.

\section{2 mIHF is a highly soluble, alpha helical DNA-binding protein}

321 The mIHF protein was purified to homogeneity with a concentration of $60 \mathrm{mg} \mathrm{ml}^{-1}$ and 322 displayed elevated stability at room temperature. The structural features of mIHF were characterized via circular dichroism (CD) spectroscopy. Fig. 2a illustrates the mean residue ellipticity of mIHF wt and its R90E mutant. 

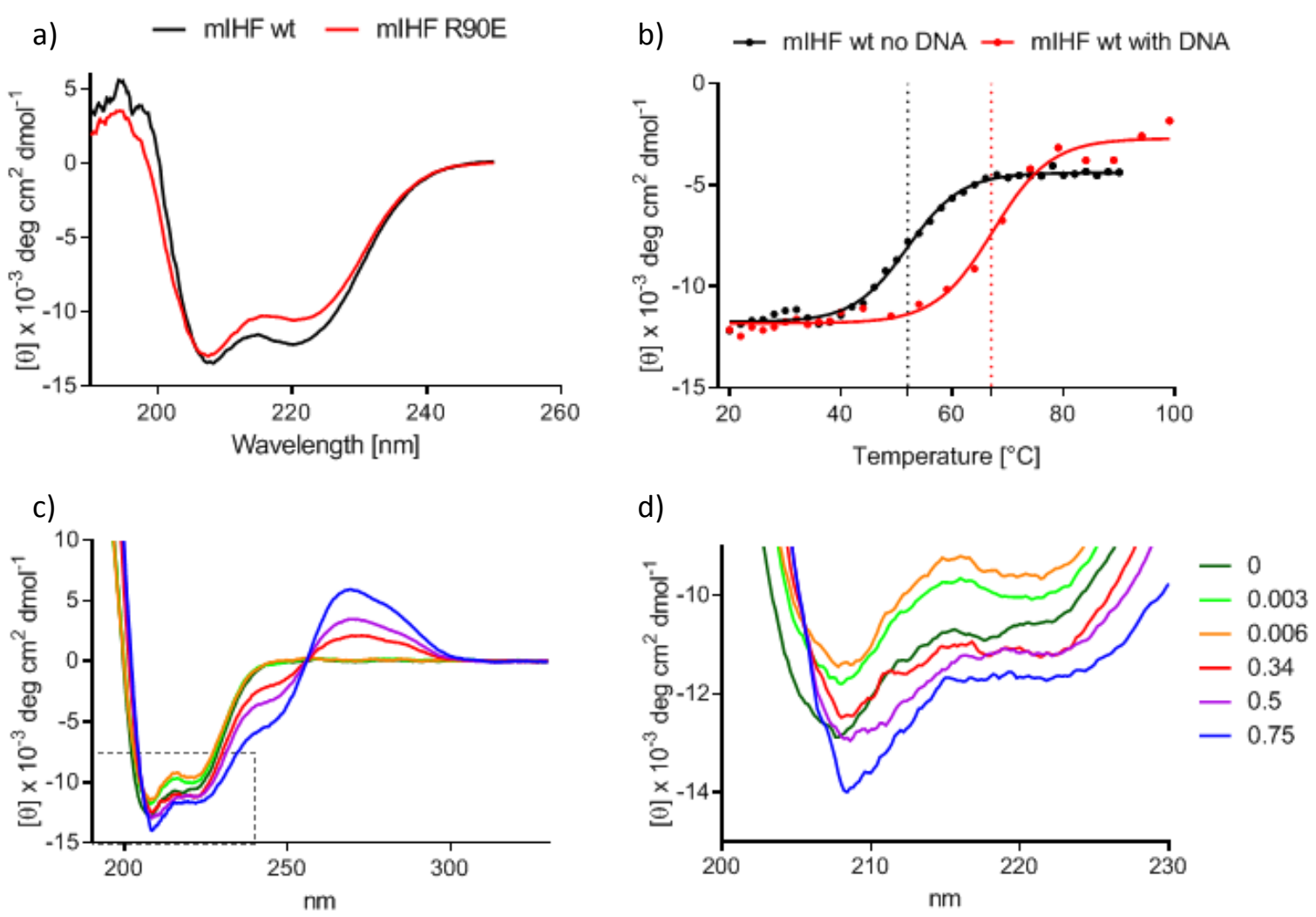

e)

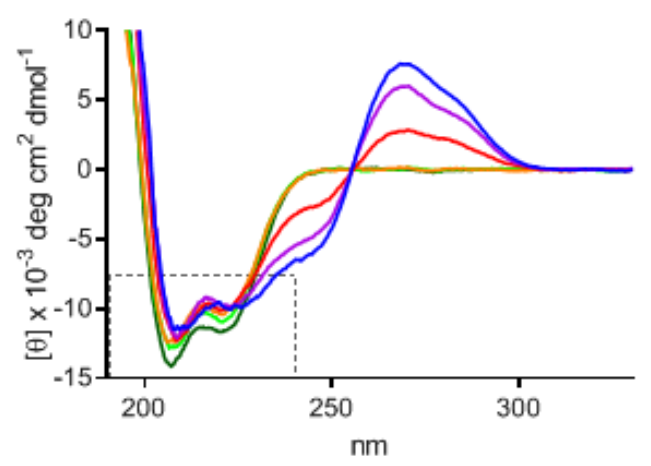

f)

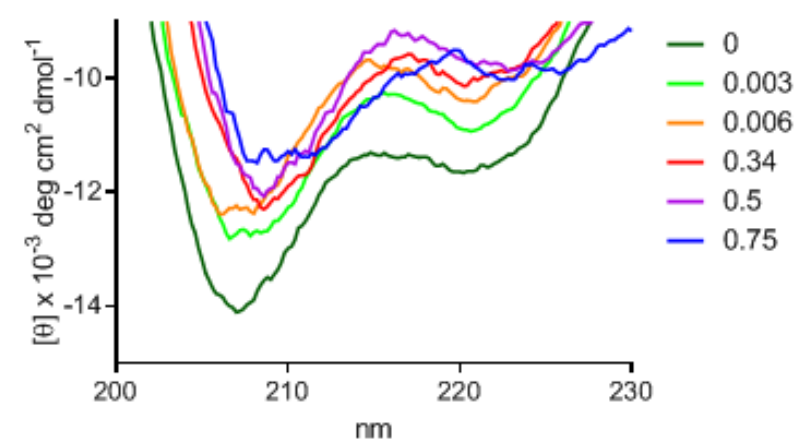

Fig. 2. Circular dichroism (CD) spectra of mIHF protein mutants. a) CD spectra of mIHF wt and mIHF R90E. b) Thermal unfolding of mIHF wt in absence and presence of dsDNA at $222 \mathrm{~nm}$. Dotted lines indicate melting temperature with (red) and without (black) DNA. c) CD spectra of mIHF wt with DNA titration and zoom of minima representing alpha helices (d). Different DNA equivalents were used as indicated. e) CD spectra of mIHF R90E with DNA titration and zoom (f), as for mIHF wt.

Both proteins showed a folded structure dominated by alpha helices, as reflected in the two pronounced negative peaks at 208 and $222 \mathrm{~nm}$. mIHF R90E displayed a minor deviation from mHIF wt, suggesting that their overall secondary structures are very similar but not completely identical. The CD signal at $222 \mathrm{~nm}$, as a function of temperature, was fitted to a 
sigmoidal non-linear model and the melting temperature was calculated as $52^{\circ} \mathrm{C}$ (Fig. $2 \mathrm{~b}$ ). The protein did not refold into its alpha helical structure at $20^{\circ} \mathrm{C}$ after heating to $95^{\circ} \mathrm{C}$. The melting temperature increased to $67^{\circ} \mathrm{C}$ in the presence of DNA, suggesting higher stability of mIHF when bound to DNA (Fig. 2b). To screen for conformational changes in the mIHF protein upon DNA binding, the wt and mutant proteins were incubated with very low 0.003 and 0.006 equivalents) and increasingly higher amounts $(0.34,0.5,0.75$ equivalents) of a 40 bp dsDNA oligonucleotide. The minima at $208 \mathrm{~nm}$ and at $222 \mathrm{~nm}$ became less pronounced in mIHF wt at low amounts of DNA, indicating a small conformational change with no emergence of a different secondary structure. At higher DNA/protein ratios, a deeper minima at $208 \mathrm{~nm}$ appeared (Fig. 2c and zoom in Fig. 2d). mIHF R90E showed a similar pattern with a decrease in both $208 \mathrm{~nm}$ and $220 \mathrm{~nm}$ minima, but no subsequent increase at high DNA concentrations. To assess how the mIHF protein shifted linear DNA, a 700 bp DNA fragment was incubated with mIHF wt and mIHF R90E in a gel retardation assay. While mIHF wt shifted the DNA effectively, mIHF R90E had a markedly lower retardation effect (Fig. 3).

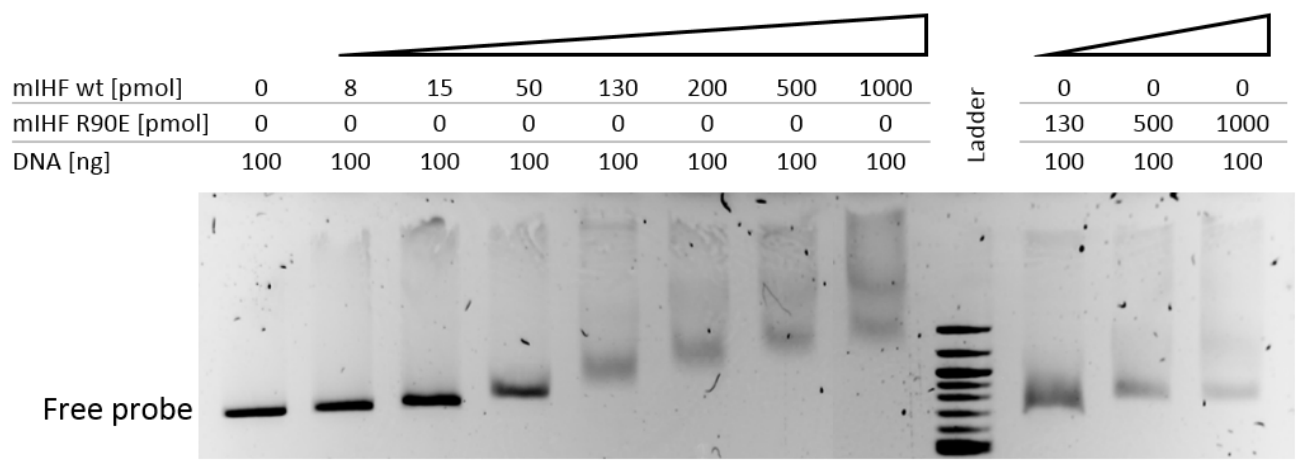

Fig. 3. Gel retardation assay obtained upon incubation of a 700 bp DNA fragment with mIHF or with mIHF R90E. DNA was incubated with increasing concentrations of $\mathrm{mIHF}$ as detailed in the image and run on a $0.75 \%$ agarose gel. Post-run staining was performed with GelRed. Ladder: 100 bp molecular weight marker.

This confirmed that R90 is important for DNA binding by mIHF. The minor DNA shift caused by mIHF R90E suggested that the mutant protein is still capable of binding DNA, confirming the $C D$ results, but with a decreased DNA binding strength compared to mIHF wt. Thus, mIHF R90E represented a suitable control for other DNA-mIHF interaction experiments. 
In order to define the exact binding mechanism and interaction with DNA, structure determination of mIHF was carried out in solution by NMR spectroscopy. High-dimensional automated projection spectroscopy (APSY) spectra for backbone assignment and $3 \mathrm{D}{ }^{15} \mathrm{~N} /{ }^{13} \mathrm{C}$ HSQC-NOESY spectroscopy to obtain side-chain resonance assignments and conformational restraints were acquired (Table 1 ).

Table 1. NMR structural statistics.

\section{NMR constraints}

\begin{tabular}{l|l}
\hline Distance & 1818 \\
\hline Intra-residue $(|i-j|=0)$ & 429 \\
\hline Inter-residue & 613 \\
$\quad$ Sequential $(|i-j|=1)$ & 542 \\
$\quad$ Medium range $(1 \leq|i-j| \leq 4)$ & 234 \\
Long-range $(|i-j|>5)$ & 181 \\
TALOS+ dihedral angle restraints & 0.99 \\
Backbone RMSD from mean structure & \\
(residue 18 - 107) $[\AA]$ & $85.2 \%$ \\
Ramachandran analysis & $13.6 \%$ \\
\hline most favoured & $1.0 \%$ \\
\hline additional allowed & $0.2 \%$ \\
\hline generously allowed & \\
Disallowed & \\
\hline
\end{tabular}

367 The backbone and total atom assignments were completed to $90.24 \%$ and $76.71 \%$, respectively. An additional four amino acids (GSHM) remained after removal of the His-tag; the mIHF protein therefore starts at residue number 5 . Note that the NMR statistics (Table 1) concern the entire construct from residues 1 to 109, and the residue numbering in the following section refers to the protein construct used for the NMR study. mIHF was identified as a globular protein (Fig. 4a) for residues 12 - 107 with an RMSD (root mean square deviation of atomic positions) of $1.45 \AA$ or $1.11 \AA$ for residues $16-107$, excluding the first four $\mathrm{N}$-terminal helical residues which show increased conformational spread. The $\mathrm{N}$ terminal domain of the mIHF protein (residues V5-T11) did not form a defined secondary 
$\mathrm{N}$-terminus

a)

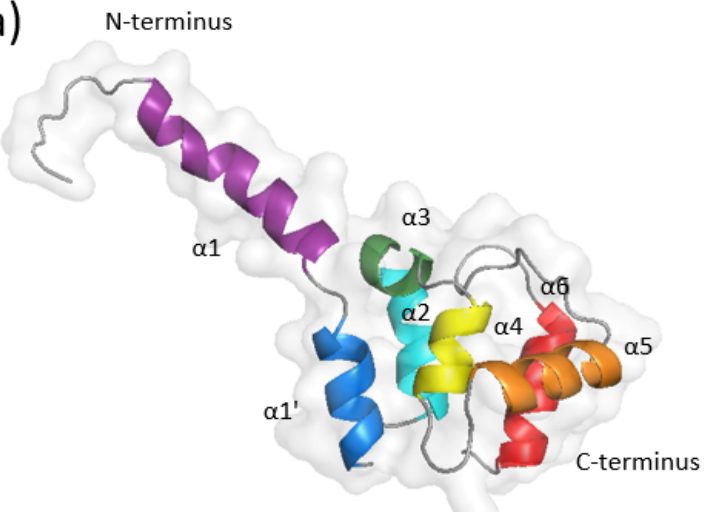

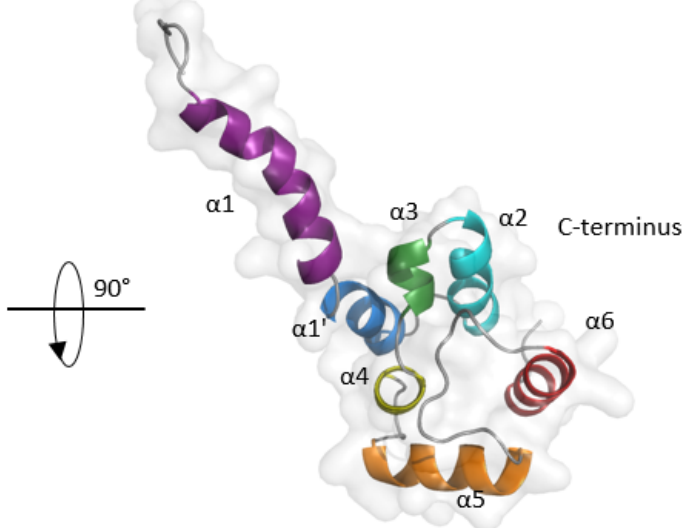

378

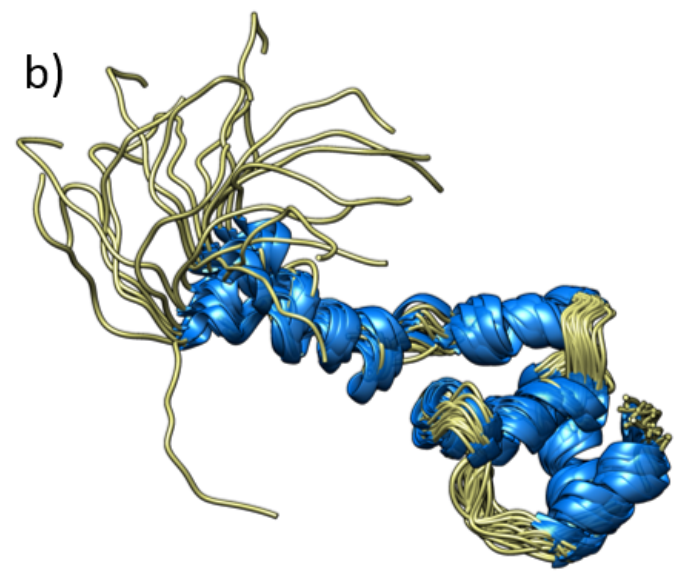

c)

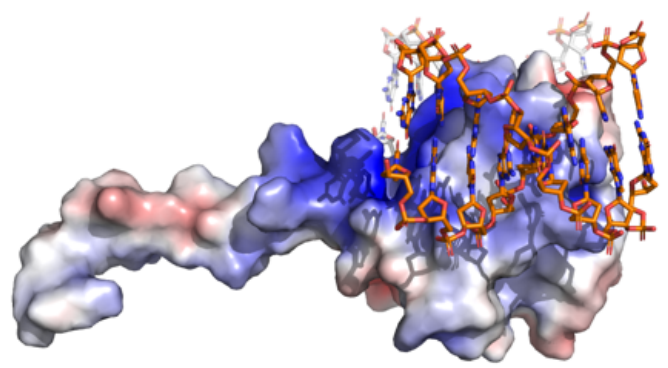

Fig. 4 Structure of mIHF. a) Ribbon drawing of mIHF (90 rotated around z-axis). b) Overlay of the 20 lowest energy structures of mIHF. c) Surface charge of mIHF, blue representing positively and red negatively charged surface of mIHF. DNA (red) is superimposed from PDPB ID 4ITQ after alignment of the sIHF protein to mIHF.

Overall, the NMR structure of mIHF resembled closely the sIHF X-ray structure with an overlay backbone RMSD of $1.62 \AA$ and a similar topology with six $\alpha$-helices. The flexible $\mathrm{N}$ terminal end of mIHF is constituted by residues V 5 to R15 followed by the first $\alpha$-helix $(\alpha 1)$ comprising A16 to R38. This helix was predicted to form a coiled coil and might be the site of dimerization for mIHF. A minor kink at residues A28 and R29 caused a slight divergence from an optimal helix. $\alpha 1$ is connected by a five-residue loop to $\alpha 2$, a short helix from L47 to E54. $\alpha 3$ only spans one turn from K57 to V61 and is followed by $\alpha 4$ from L64 - K70, $\alpha 5$ (Q77 P87) and finally $\alpha 6$ (A101 - A109) (Fig. 4b). 
Backbone assignments by UNIO-MATCH were completed to $90.24 \%$. To probe the internal dynamics of $\mathrm{mIHF}$ and its aggregation state, three relaxation parameters for each backbone amide were characterized: the longitudinal and transverse ${ }^{15} \mathrm{~N}$ relaxation rates $R_{1}=1 / T_{1}$ and $R_{2}=1 / T_{2}$, respectively, as well as the steady state heteronuclear Overhauser effect $\left(\left\{{ }^{1} H\right\}^{15} \mathrm{~N}\right.$ NOE). ${ }^{15} \mathrm{~N}$ relaxation data are related to the correlation time of the reorientation motion of the $\mathrm{H}-\mathrm{N}$ bonds due to protein dynamic in solution. For globular proteins in solution this is primarily due to the molecular rotational correlation time, which in turn is related to the molecular hydrodynamic radius. We can derive the molecular rotational correlation time from the $T_{1} / T_{2}$ ratio for the 44 most rigid residues (with $\left\{{ }^{1} H\right\}-{ }^{15} N$ NOE $>0.65$, and neglecting the internal dynamics) that provided a rotational correlation time of $6.9 \pm 1.7 \mathrm{~ns}$ (at $298 \mathrm{~K}$ ), which is in line with a molecular weight of 10-12 kDa. In the supporting information the measured values of ${ }^{15} \mathrm{~N} R_{1}, R_{2}$ and $\left\{{ }^{1} H\right\}^{-15} \mathrm{~N}$ NOE were reported in table $\mathrm{S} 2$ and plotted in Fig. S4.

\section{4 mlHF binds to double-stranded DNA and has two distinct DNA-binding} domains

The ligand binding affinity of purified mIHF protein with dsDNA was determined by isothermal titration calorimetry (ITC). mIHF can bind dsDNA of different lengths, with affinity constants in the low micromolar range. The dissociation constant $\left(K_{D}\right)$ values for 7,16 and 40 bp dsDNA were 6.08, 2.39 and $9.16 \mu \mathrm{M}$, respectively (Fig. S5 a, b, c). Binding was only observed for dsDNA, but not for ssDNA oligonucleotides of the same lengths (Fig. S5 d, e, f).

To investigate the interaction of mIHF with dsDNA in structural terms, we performed a titration of $200 \mu \mathrm{M}{ }^{15} \mathrm{~N}$-labelled protein with $16 \mathrm{bp}$ dsDNA and monitored the effects of DNA addition on mIHF by solution NMR (Figure 5). Specifically, we titrated a dsDNA molecule of sequence $5^{\prime}$-AGCTCGTCAACGCCTT- 3 ' into ${ }^{15} \mathrm{~N}$-labelled protein and acquired ${ }^{1} \mathrm{H}-{ }^{15} \mathrm{~N}$ HSQC spectra at $0,0.25,0.50,1.0$ and 2.20 equivalents (dsDNA/protein ratios). Analysis of the titration data relied on the backbone ${ }^{1} \mathrm{H}$ and ${ }^{15} \mathrm{~N}$ assignments obtained from the automated assignment and structure calculation procedures, which we verified and completed by inspecting CBCANH and $\mathrm{HN}(\mathrm{CA}) \mathrm{CO}$ 3D spectra (See fig. S1 / S2 for confirmation of assignments). Of the non-proline residues, only the four $\mathrm{N}$-terminal residues plus L19, R27 through $\mathrm{A} 30$ and $\mathrm{R} 97$ lack backbone $\mathrm{H}$ and $\mathrm{N}$ shifts in our final assignment, and hence were not included in the analysis. 
Effects on mIHF HSQC spectra were evident already at 0.25 equivalents, as we observed the shifting and broadening of several crosspeaks. Figure $5 \mathrm{~A}$ illustrates this on a region of the HSQC spectrum, with well-resolved crosspeaks, that exemplifies K70 broadening beyond detection and several other crosspeaks experiencing large shifts. Resonance broadening suggests exchange kinetics in the millisecond-microsecond timescale, which is consistent with an affinity in the micromolar range as determined by ITC. To better define the chemical shift perturbations, we continued the titration recording spectra at 0.50 , 1.0 and 2.2 equivalents, increasing the number of scans as required to compensate for the broader signals. Figure 5B presents a plot of intensity ratios at 0.25 equivalent (where effects are already strong but most signals are still intense enough for quantification) and Figure 5C presents the chemical shift perturbations at 2.2 equivalents (where they are largest). Figure 5D in turn maps these intensity drops and chemical shift perturbations onto the mIHF structure. We observe clustering of the residues most affected by intensity loss or shifts in two sites, which is consistent with dsDNA bound to the two sites identified in the X-ray structure of sIHF bound to DNA (Swiercz et al., 2013). This is relevant because it means that the two sites identified for slHF across the crystallographic unit cell are not merely an artefact of crystallization, but actual binding sites functional in solution. Residues K33, K37, E66, L68, K70, G72, K75 and A76 are all impacted by broadening (red in Figure 5D) and thus correspond to DBS-I of SIHF, together with $\mathrm{K} 73$, which experiences a large shift (blue). Residues K60, S62, L68, V71, M80, T81, T88, R89, L91, R92, G93, D96, Q98, were largely affected by chemical shift perturbation (blue in Figure 5D) and correspond to DBS-II proposed for slHF together with R90 which experiences broadening (red). Qualitatively, it appears that binding to DBS-II proceeds at a faster exchange timescale, i.e. is of lower affinity than DBS-I.

Finally, from the results of our titration, we also observed some residues undergoing chemical shift perturbations and broadening outside of the DNA interaction sites, especially on one face of the N-terminal helix: A17, K21, A23, A24. Notably, this helix has some predicted coiled coil propensity (fig. S3), which could imply weak dimerization upon DNA binding. 
a)

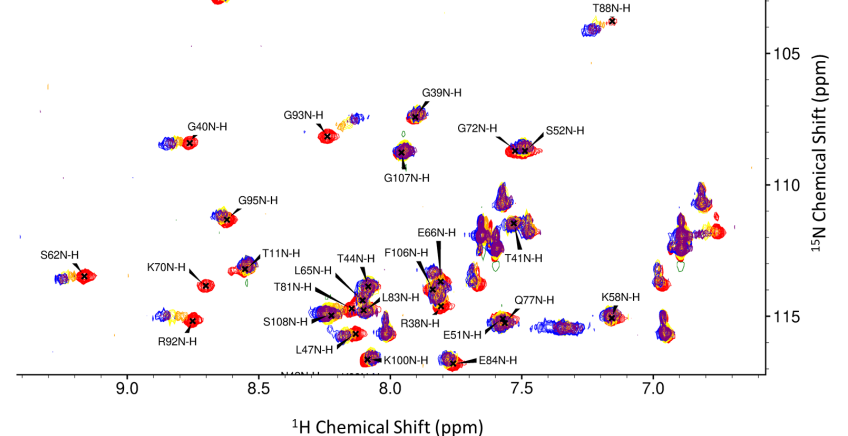

d)

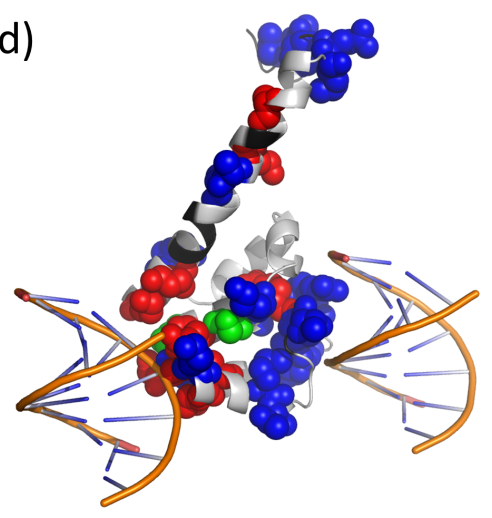

b)

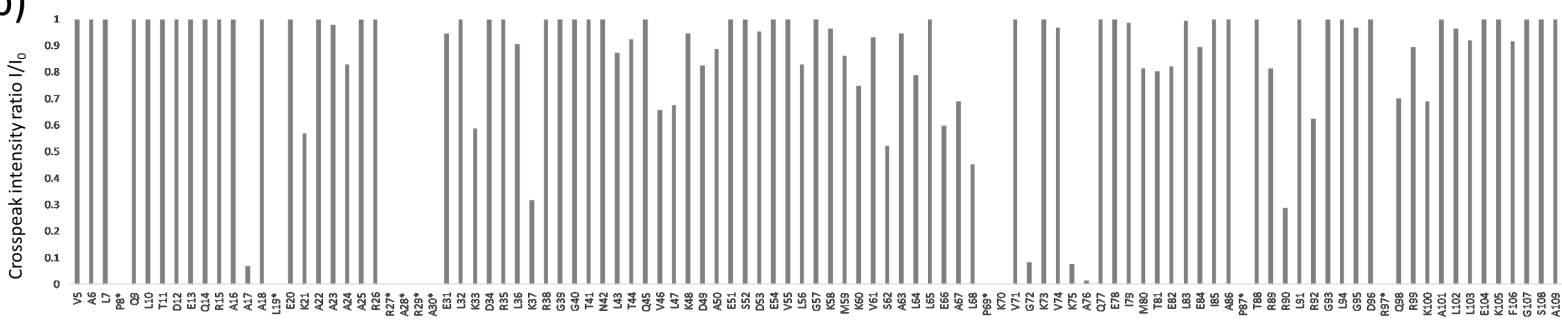

C) 0.2

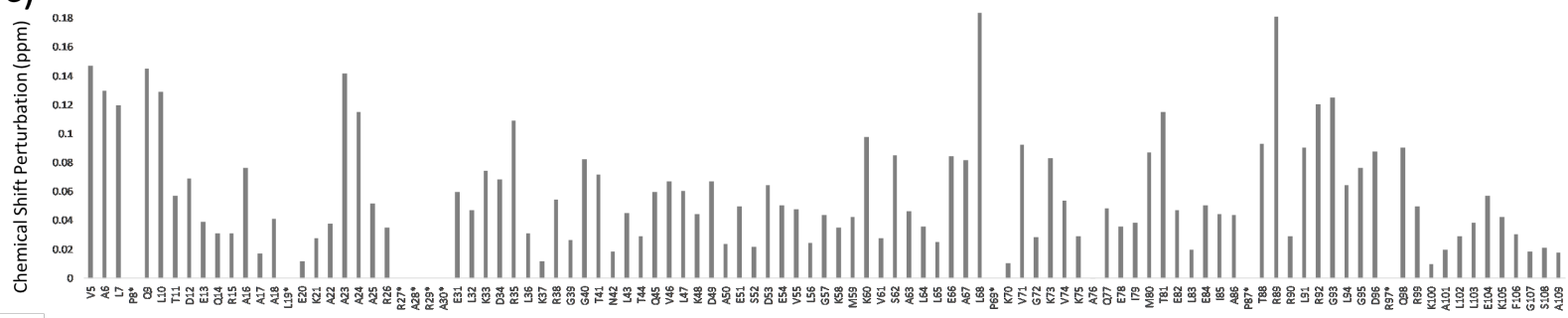

Fig. 5. Titration of double-strand DNA onto mIHF, monitored by ${ }^{1} \mathbf{H},{ }^{15} \mathrm{~N}$ HSQC spectra. a) Titration of ${ }^{15} \mathrm{~N}-\mathrm{mIHF}$ with DNA, followed through NMR spectroscopy at $800 \mathrm{MHz}{ }^{1} \mathrm{H}$ frequency. Overlay of ${ }^{1} \mathrm{H}-{ }^{15} \mathrm{~N}$ HSQC spectra without DNA (red) and with 0.25 (orange), 0.50 (green), 1 (purple) and 2.2 equivalents of 16 bp dsDNA (blue). b) Residue-wise ratio of crosspeak intensities at 0.25 equivalents (DNA/protein) relative to the intensities in the spectrum of the free protein. (c) Residue-wise ${ }^{1} \mathrm{H},{ }^{15} \mathrm{~N}$ chemical shift perturbations at 2.2 DNA/protein equivalents relative to the free protein. In panels $b$ and $c$, residues labeled with an asterisk lack $H, N$ assignments or are prolines. (d) Mapping of residues displaying a sharp drop in the intensity ratios at 0.25 equivalents (red spheres, $1 / 10<0.6$ ) and of residues experiencing large chemical shift perturbations (blue spheres, CSP > $0.08 \mathrm{ppm}$ ) on a cartoon representation of mIHF NMR structure. Green spheres are for residues that experienced both large intensity drop and large chemical shift perturbations. The two dsDNA molecules are overlaid from PDB ID 4ITQ after alignment of the sIHF protein to mIHF. Cartoon portions in black correspond to residues missing $\mathrm{H}, \mathrm{N}$ assignments, marked with an asterisk in panels (b) and (c). A 3D interactive version of panel $\mathrm{b}$ is available at http://lucianoabriata.altervista.org/papersdata/mihfdnatitration.html

\section{5 mlHF introduces defined loops into linear DNA fragments} various length, topology and GC content, and imaged using AFM. The first substrate tested 
was a $1 \mathrm{~kb}$ linear fragment containing the mihF gene and the upstream promoter region with a GC content of $65 \%$, representing the mean GC content in M. tuberculosis. The DNA 472 fragment alone showed a looping probability of $10 \%$, which increased upon addition of mIHF and reached $53 \%$ when the maximum amount was added (Table S3, Fig. 6).

a)
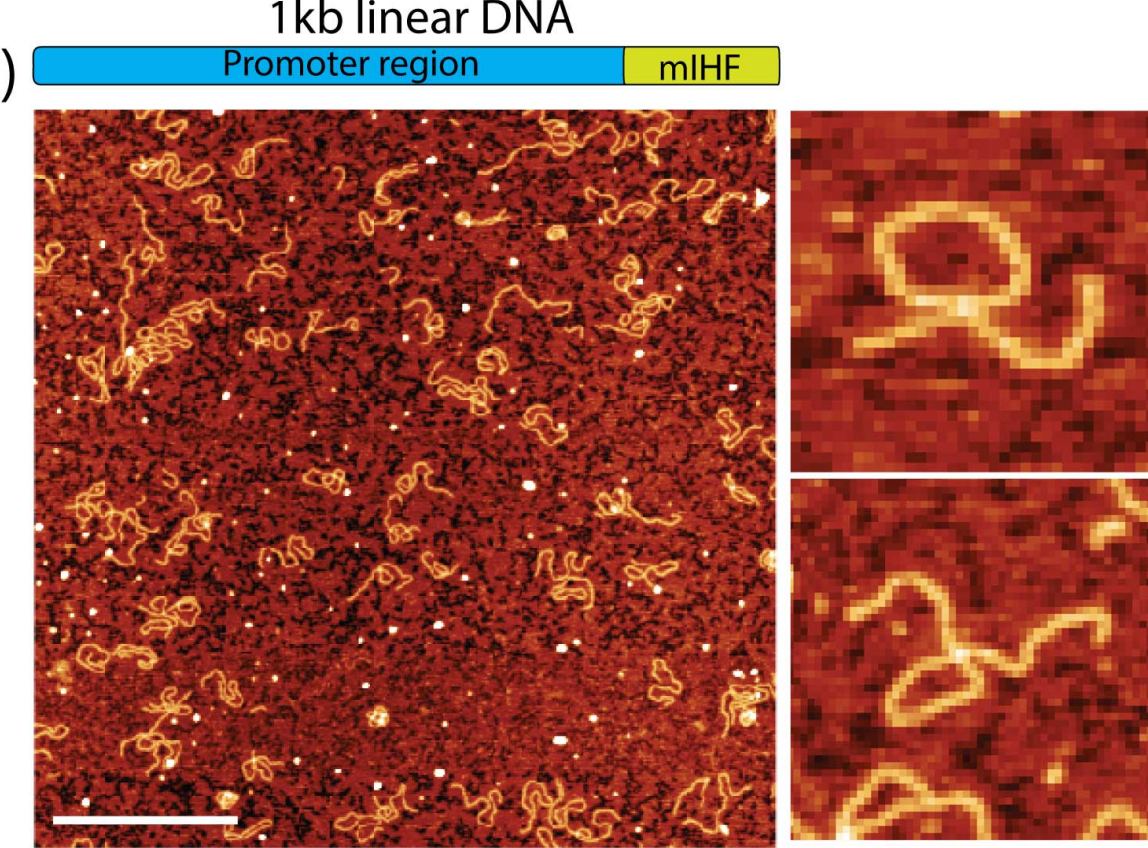

\section{Left-handed loop}
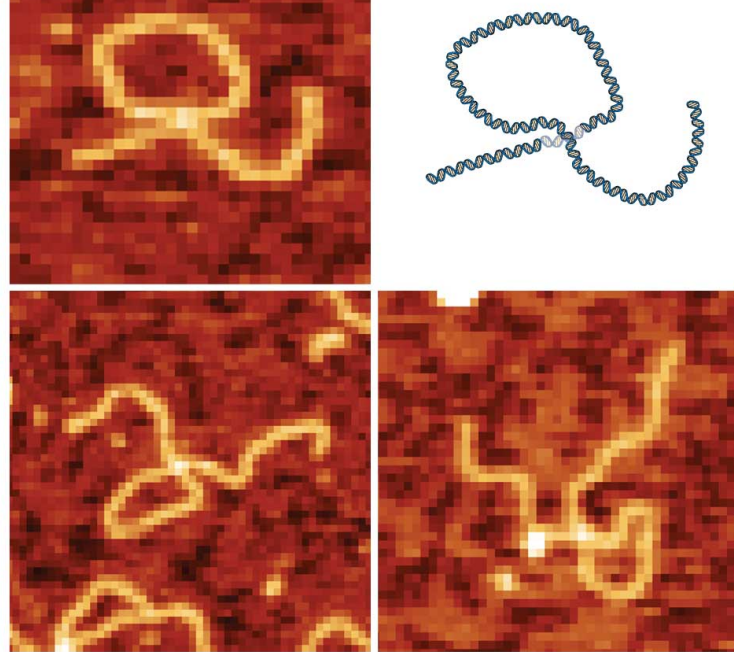

b)

C)
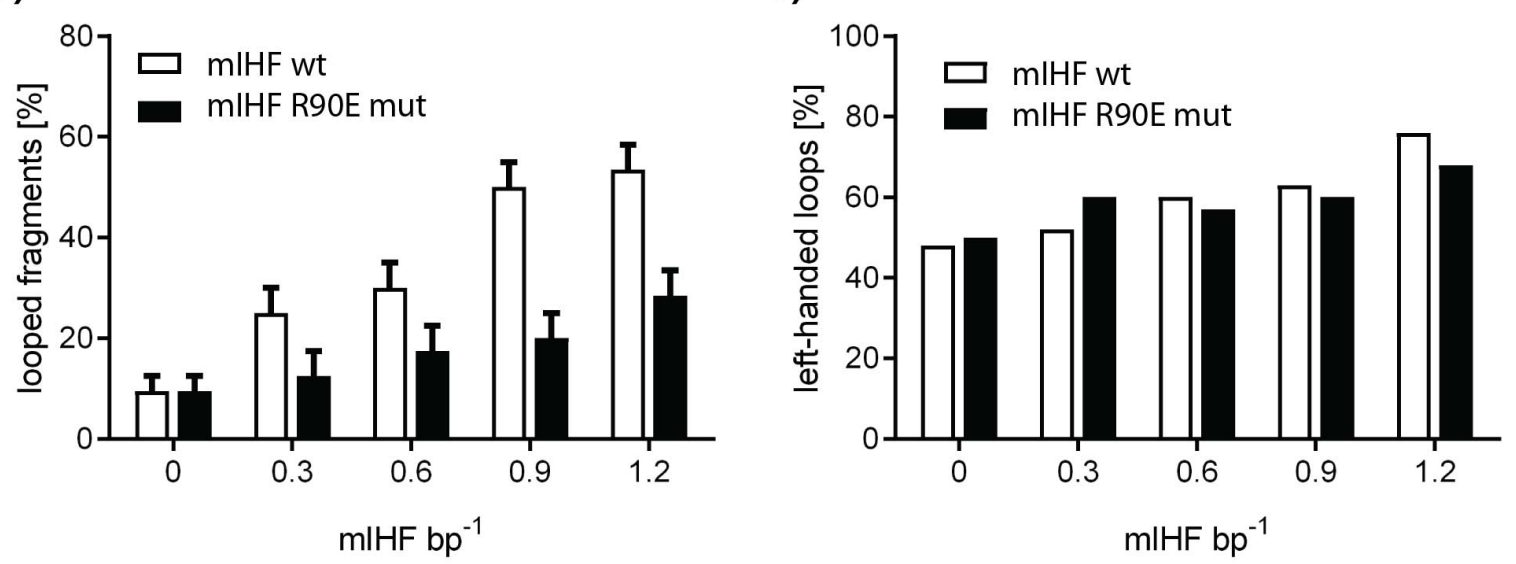

Fig. 6. Atomic force microscopy experiments. A $1 \mathrm{~kb}$ linear DNA fragment harbouring the mihF gene and its promoter region was incubated with the mIHF protein. a) Image of DNA fragments and zoomed images of looped structures at $0.21 \mathrm{mIHF} \mathrm{bp}^{-1}$. Scale bar represents $500 \mathrm{~nm}$. b) and c) Graphs representing the mean percentage \pm standard deviation of looped fragments observed upon addition of increasing concentrations of mIHF wt and mIHF R90E and the percentage of left-handed loops. 
481

The size of the loops was well defined with a mean length of $110 \pm 10 \mathrm{~nm}$, which corresponds to ca. $300 \mathrm{bp}$ (Table S4). When the same experiment was repeated with mIHF R90E, loops in the linear DNA were observed as well but with a lower ratio compared to the wt protein. Only $28 \%$ looped fragments were detected upon binding of mIHF R90E at the same maximal concentration (Table S3, Fig. 6b). The average loop length was similar for mIHF and mIHF R90E with $110.5 \pm 10 \mathrm{~nm}$ and $106.75 \pm 10 \mathrm{~nm}$, respectively (Table S4). These results indicated that mIHF R90E did exhibit DNA binding activity, but to a lower extent compared to the wt protein, confirming the gel retardation assay results. Naked DNA had approximately $50 \%$ left- and right-handed loops, corresponding to positive and negative supercoiling, respectively. mIHF wt, as well as mIHF R90E, increased the number of lefthanded loops in a concentration-dependent manner to $76 \%$ for the wt protein and to $68 \%$ for the mutant (Fig. 6c, Table S5).

\subsection{Large cosmids unwind and compact in an mIHF concentration dependent}

\section{manner}

The M. tuberculosis chromosome is a circular, supercoiled macromolecule of $4.4 \mathrm{Mb}$ in length. Topology and size are not correctly represented by short linear DNA fragments or plasmids. Furthermore, bacterial chromatin is organized into microdomains of ca. $10 \mathrm{~kb}$ (Dame and Tark-Dame, 2016), a compartmentalization that cannot be mimicked by plasmids. Therefore, we used the $42.6 \mathrm{~kb} 195$ supercoiled cosmid (Bange et al., 1999) to reproduce more closely the features of the genomic DNA. Supercoiled 195 forms highly ordered structures, the so-called hyperplectonemes, only present in DNA molecules above $30 \mathrm{~kb}$ in size (Japaridze et al., 2017). Incubation of 195 with mIHF wt at low concentrations (0.6 mIHF $\mathrm{bp}^{-1}$ ) led to unwinding of the cosmid from the hyperplectonemic form and reduced its complexity (Fig. 7). 
a)
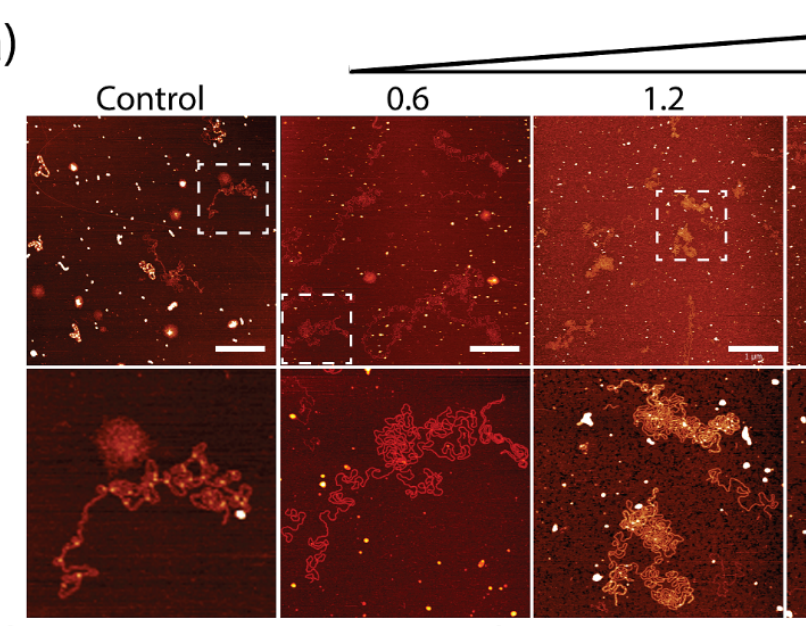

b)

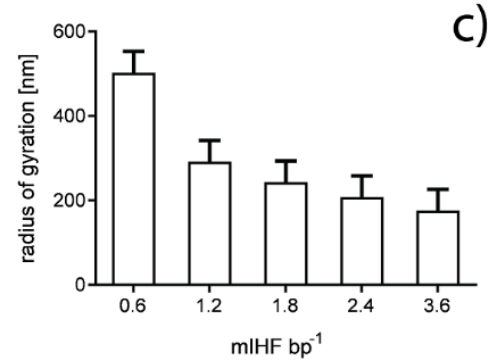

c)

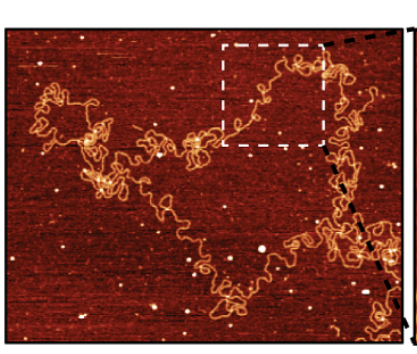

mIHF : bp ratio

3.6

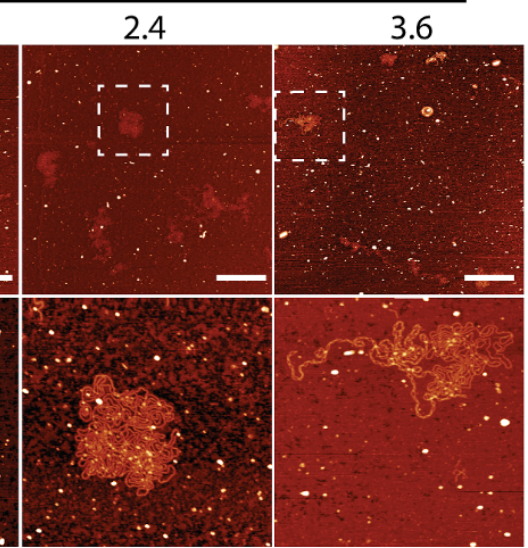

d)

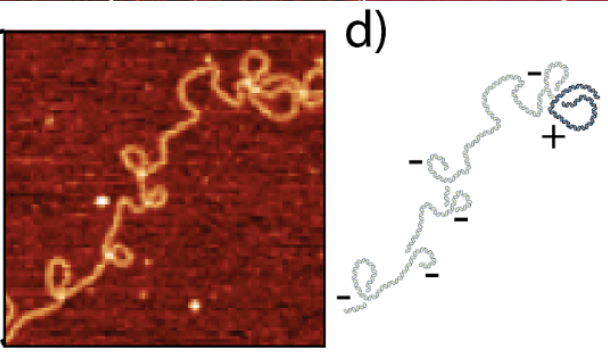

505

506

507

508

509

510

511

512

513

514

515

516

517

518

519

520

Fig. 7. Atomic force microscopy experiments with cosmid 195. a) Cosmid 195 alone and incubated with increasing concentrations of mIHF wt. The lower panels are zoomed images of the squares defined in the upper panels. Scale bar represents $1 \mu \mathrm{m}$ and $\mathrm{mIHF} \mathrm{bp}^{-1}$ ratios are indicated above images. b) Radius of gyration measured for cosmids in the presence of mIHF. Bars represent mean \pm standard deviation. c) Cosmid 195 incubated with 1.2 mIHF bp ${ }^{-1}$, zoom to an example structure and handedness of loops (“-” = left-handed, “+” = right-handed, (d)).

At higher mIHF ratios (1.2 to $3.6 \mathrm{mlHF} \mathrm{bp}^{-1}$ ), the cosmid collapsed and condensed again, as illustrated by the decrease in radius of gyration (smallest circle that contains the DNA polymer, Fig. 7b, Table S6). Re-compaction of the cosmid at high mIHF ratios only reached first-order plectonemes, but did not lead to the formation of hyperplectonemes like those observed in the absence of protein. Similar to the loops observed on the linear DNA fragment, mIHF also introduced mostly left-handed loops in the cosmid, as illustrated in Fig. 7c and d. The R90E mutant simplified the topology of 195, but no collapse was visible at higher ratios of the protein, in agreement with the reduced DNA-binding observed with linear DNA (Fig. S6). 


\section{Discussion and conclusion}

The importance of mIHF in M. tuberculosis physiology was suggested by Schubert and colleagues, whose mass spectrometry experiments predicted the protein to be among the ten most abundant proteins in the bacterium (Schubert et al., 2015). This initial indication was confirmed by our genetic studies, where we proved the essentiality of the gene and the role of the protein in controlling transcription of a variety of virulence factors and housekeeping genes (Odermatt et al., 2018). Here, we investigated the structure of mIHF and its DNA binding properties.

High similarity to the homologue sIHF from S. coelicolor was already evident from the primary structure alignment and further validated by the NMR structure, which differed for only $1.3 \AA$ compared to the sIHF crystal structure. mIHF formed a globular protein with a protruding $\alpha$-helix at the $\mathrm{N}$-terminal end and the core of the protein consisted of five short $\alpha$-helices.

ITC confirmed a $K_{D}$ in the low micromolar range, corresponding to a medium-high affinity of the transcription factor for dsDNA. Further, the difference in $K_{D}$ for different substrate lengths ranged only four-fold, suggesting no preference for DNA length. No binding was observed to SSDNA, and similar results were obtained by Swiercz et al., who showed a much higher affinity of sIHF for dsDNA than for ssDNA (Swiercz et al., 2013).

ITC and NMR titrations of mIHF with DNA, and temperature stabilization of mIHF in presence of DNA, all clearly indicate that mIHF binds specifically double stranded DNA molecules. In particular, mapping of binding sites by NMR spectroscopy indicates binding on two sites that are consistent with those identified in the X-ray structure of slHF. High-resolution AFM images showed that incubation of mIHF with a $1 \mathrm{~kb}$ linear DNA fragment introduced loops of a defined size. Such DNA loops are commonly associated with regulation of gene expression in bacteria, best described in the lac operon of E. coli, where Lacl activates transcription by looping the promoter region and by constraining supercoils (Fulcrand et al., 2016). Although mIHF does appear to bind DNA in a sequence-independent manner, it affects the expression of many genes in $M$. tuberculosis (Odermatt et al., 2018). The mIHF protein might therefore have a direct effect on gene expression by looping the DNA and by bringing other regulatory elements closer to the target gene. Support for this is provided by the large number of loci occupied by mIHF and other NAPs, such as EspR (Odermatt et al., 2018). 76\% of the loops 
552 observed at the highest protein:DNA ratio $\left(1.22 \mathrm{mIHF} \mathrm{bp}{ }^{-1}\right)$ were of left-handed orientation.

553

554

555

556

557

558

559

560

561

562

563

564

565

566

567

568

569

570

571

572

573

574

575

576

577

578

Naturally, DNA in bacterial cells is tightly packed in negative supercoils as exemplified by the 195 cosmid. Introduction of left-handed loops by mIHF relaxed and opened the cosmid, thus making it potentially accessible to replication and transcription machineries. Indeed, mIHF was found to act mainly as a transcriptional activator (Odermatt et al., 2018). This pattern is similar to that caused by E. coli HU on cosmid 195, where ordered, regular, left-handed loops were observed (Japaridze et al., 2017). Similarly to mIHF, E. coli HU binds without sequence specificity to DNA, but prefers gapped and cruciform DNA (Pinson et al., 1999). On the contrary, M. tuberculosis EspR introduced loops and additional twists into the DNA (Blasco et al., 2012). Therefore, it appears that mIHF and EspR have divergent effects on the DNA topology of the tubercle bacillus.

In conclusion, we showed here that mIHF has a globular structure, comprising six alpha helices, that is similar overall to that of sIHF despite the divergent sequences. The protein has two DNA binding sites that are functional in solution. DNA binding plays an important role in shaping the DNA structure by introducing left-handed loops. We propose these DNA binding capabilities could possibly be involved in promoting transcription.

\section{Acknowledgments}

We would like to thank the mass spectrometry facility at EPFL for their technical support and Stefanie Boy-Röttger for technical support. This work was supported by the Swiss National Science Foundation (grant 31003A-162641 to STC) and by H2020-INFRAIA iNEXT (grant 653706) for supporting the NMR instrument time in the Lyon CRMN platform.

\section{Author contributions}

NTO conceived the experiments, carried out the wet lab experiments, ML and TH determined the NMR structure of mIHF, LAA verified resonance assignments and performed and analysed the NMR titration, AJ and HV did the AFM studies, RS performed the ICT experiment, JP suggested the mutations, LE, GV and STC supervised the study. NTO, LAA and STC wrote the manuscript. 


\section{References}

Altschul SF, Gish W, Miller W, Myers EW, Lipman DJ, 1990. Basic local alignment search tool. J. Mol. Biol. 215, 403-410. https://doi.org/10.1016/S0022-2836(05)80360-2

Balleza, E., López-Bojorquez, L.N., Martínez-Antonio, A., Resendis-Antonio, O., LozadaChávez, I., Balderas-Martínez, Y.I., Encarnación, S., Collado-Vides, J., 2009. Regulation by transcription factors in bacteria: Beyond description. FEMS Microbiol. Rev. 33, 133-151. https://doi.org/10.1111/j.1574-6976.2008.00145.x

Bange, F.C., Collins, F.M., Jacobs, W.R., 1999. Survival of mice infected with Mycobacterium smegmatis containing large DNA fragments from Mycobacterium tuberculosis. Tuber. Lung Dis. 79, 171-180. https://doi.org/10.1054/tuld.1998.0201

Bhowmick, Bhowmick, T., Ghosh, S., Dixit, K., Ganesan, V., Ramagopal, U. a, Dey, D., Sarma, S.P., Ramakumar, S., Nagaraja, V., 2014. Targeting Mycobacterium tuberculosis nucleoid-associated protein HU with structure-based inhibitors. Nat. Commun. 5, 4124. https://doi.org/10.1038/ncomms5124

Blasco, B., Chen, J.M., Hartkoorn, R., Sala, C., Uplekar, S., Rougemont, J., Pojer, F., Cole, S.T., 2012. Virulence regulator EspR of Mycobacterium tuberculosis is a nucleoid-associated protein. PLoS Pathog. 8, e1002621. https://doi.org/10.1371/journal.ppat.1002621

Blasco, B., Stenta, M., Alonso-Sarduy, L., Dietler, G., Peraro, M.D., Cole, S.T., Pojer, F., 2011. Atypical DNA recognition mechanism used by the EspR virulence regulator of Mycobacterium tuberculosis. Mol. Microbiol. 82, 251-64. https://doi.org/10.1111/j.1365-2958.2011.07813.x

Boshoff, H.I.M., Barry, C.E., 2005. Tuberculosis - Metabolism and respiration in the absence of growth. Nat. Rev. Microbiol. 3, 70-80. https://doi.org/10.1038/nrmicro1065

Cavanagh, J., Fairbrother, W., III, A.P., Skelton, N., 2007. Protein NMR Spectroscopy, 2nd Edition Principles and Practice, Current biology. https://doi.org/10.1016/B978012164491-8/50005-1

Colangeli, R., Haq, a, Arcus, V.L., Summers, E., Magliozzo, R.S., McBride, a, Mitra, a K., Radjainia, M., Khajo, a, Jacobs, W.R., Salgame, P., Alland, D., 2009. The multifunctional 
histone-like protein Lsr2 protects mycobacteria against reactive oxygen intermediates. Proc. Natl. Acad. Sci. U. S. A. 106, 4414-8. https://doi.org/10.1073/pnas.0810126106

Dame, R.T., Tark-Dame, M., 2016. Bacterial chromatin: converging views at different scales. Curr. Opin. Cell Biol. 40, 60-65. https://doi.org/10.1016/j.ceb.2016.02.015

Dillon, S.C., Dorman, C.J., 2010. Bacterial nucleoid-associated proteins, nucleoid structure and gene expression. Nat. Rev. Microbiol. 8, 185-95. https://doi.org/10.1038/nrmicro2261

Dorman, C.J., 2004. H-NS: a universal regulator for a dynamic genome. Nat. Rev. Microbiol. 2, 391-400. https://doi.org/10.1038/nrmicro883

Farer, L., Lowell, A., Meador, M., 1979. Extrapulmonary tuberculosis in the United States. Am J Epidemiol 109, 205-217. https://doi.org/https://doi.org/10.1093/oxfordjournals.aje.a112675

Fiorito, F., Herrmann, T., Damberger, F.F., Wüthrich, K., 2008. Automated amino acid sidechain NMR assignment of proteins using 13C- and 15N-resolved 3D [1H, 1H]-NOESY. J. Biomol. NMR 42, 23-33. https://doi.org/10.1007/s10858-008-9259-x

Fiorito, F., Hiller, S., Wider, G., Wüthrich, K., 2006. Automated resonance assignment of proteins: 6D APSY-NMR. J. Biomol. NMR 35, 27-37. https://doi.org/10.1007/s10858006-0030-x

Fulcrand, G., Dages, S., Zhi, X., Chapagain, P., Gerstman, B.S., Dunlap, D., Leng, F., 2016. DNA supercoiling, a critical signal regulating the basal expression of the lac operon in Escherichia coli. Sci. Rep. 6, 19243. https://doi.org/10.1038/srep19243

Gomez, J.E., McKinney, J.D., 2004. M. tuberculosis persistence, latency, and drug tolerance. Tuberculosis 84, 29-44. https://doi.org/10.1016/j.tube.2003.08.003

Gordon, B.R.G., Li, Y., Wang, L., Sintsova, A., van Bakel, H., Tian, S., Navarre, W.W., Xia, B., Liu, J., 2010. Lsr2 is a nucleoid-associated protein that targets AT-rich sequences and virulence genes in Mycobacterium tuberculosis. Proc. Natl. Acad. Sci. U. S. A. 107, 51549. https://doi.org/10.1073/pnas.0913551107 
determine the thermodynamics of protein unfolding and binding interactions. Nat. Protoc. 1, 2527-2535. https://doi.org/10.1038/nprot.2006.204

Gröschel, M.I., Sayes, F., Simeone, R., Majlessi, L., Brosch, R., 2016. ESX secretion systems: mycobacterial evolution to counter host immunity. Nat. Rev. Microbiol. 14, 677-691. https://doi.org/10.1038/nrmicro.2016.131

Herrmann, T., Güntert, P., Wüthrich, K., 2002a. Protein NMR structure determination with automated NOE-identification in the NOESY spectra using the new software ATNOS. J. Biomol. NMR 24, 171-189. https://doi.org/10.1016/S0022-2836(02)00241-3

Herrmann, T., Güntert, P., Wüthrich, K., 2002b. Protein NMR structure determination with automated NOE assignment using the new software CANDID and the torsion angle dynamics algorithm DYANA. J. Mol. Biol. 319, 209-227. https://doi.org/10.1016/S00222836(02)00241-3

Hiller, S., Fiorito, F., Wuthrich, K., Wider, G., 2005. Automated projection spectroscopy (APSY). Proc. Natl. Acad. Sci. 102, 10876-10881.

https://doi.org/10.1073/pnas.0504818102

Hiller, S., Wider, G., Wüthrich, K., 2008. APSY-NMR with proteins: Practical aspects and backbone assignment. J. Biomol. NMR 42, 179-195. https://doi.org/10.1007/s10858008-9266-y

Japaridze, A., Muskhelishvili, G., Benedetti, F., Gavriilidou, A.F.M., Zenobi, R., De Los Rios, P., Longo, G., Dietler, G., 2017. Hyperplectonemes: A Higher Order Compact and Dynamic DNA Self-Organization. Nano Lett. acs.nanolett.6b05294. https://doi.org/10.1021/acs.nanolett.6b05294

Japaridze, A., Vobornik, D., Lipiec, E., Cerreta, A., Szczerbinski, J., Zenobi, R., Dietler, G., 2016. Toward an Effective Control of DNA's Submolecular Conformation on a Surface. Macromolecules 49, 643-652. https://doi.org/10.1021/acs.macromol.5b01827

Jones, D.T., Buchan, D., Cozzetto, D., Bryson, K., 2017. PSIPRED [WWW Document]. URL http://bioinf.cs.ucl.ac.uk/psipred/

Kay, L.E., Bull, T.E., Nicholson, L.K., Griesinger, C., Schwalbe, H., Bax, A., Torchia, D.A., 1992. 
The measurement of heteronuclear transverse relaxation times in ax3 spin systems via polarization-transfer techniques. J. Magn. Reson. 100, 538-558.

https://doi.org/10.1016/0022-2364(92)90058-F

Lew, J.M., Kapopoulou, A., Jones, L.M., Cole, S.T., 2011. TubercuList - 10 years after. Tuberculosis 91, 1-7. https://doi.org/10.1016/j.tube.2010.09.008

Luijsterburg, M.S., Noom, M.C., Wuite, G.J.L., Dame, R.T., 2006. The architectural role of nucleoid-associated proteins in the organization of bacterial chromatin: a molecular perspective. J. Struct. Biol. 156, 262-72. https://doi.org/10.1016/j.jsb.2006.05.006

Lupas, A., Van Dyke, M., Stock, J., 1991. Predicting coiled coils from protein sequences. Science (80-. ). 252, 1162-1164. https://doi.org/10.1126/science.252.5009.1162

Manganelli, R., Proveddi, R., Rodrigue, S., Beaucher, J., Gaudreau, L., Smith, I., 2004. Sigma Factors and Global Gene Regulation in Mycobacterium tuberculosis. Society 186, 895902. https://doi.org/10.1128/JB.186.4.895

Mikhaylov, A., Sekatskii, S.K., Dietler, G., 2013. DNA trace: A comprehensive software for polymer image processing. J. Adv. Microsc. Res. 8, 241-245. https://doi.org/10.1166/jamr.2013.1164

Mishra, A., Vij, M., Kumar, D., Taneja, V., Mondal, A.K., Bothra, A., Rao, V., Ganguli, M., Taneja, B., 2013. Integration Host Factor of Mycobacterium tuberculosis, mIHF, Compacts DNA by a Bending Mechanism. PLoS One 8, e69985. https://doi.org/10.1371/journal.pone.0069985

Nečas, D., Klapetek, P., 2012. Gwyddion: an open-source software for SPM data analysis. Open Phys. 10, 181-188. https://doi.org/10.2478/s11534-011-0096-2

Notredame, C., Higgins, D.G., Heringa, J., 2000. T-Coffee: A novel method for fast and accurate multiple sequence alignment. J. Mol. Biol 302.

Odermatt, N.T., Sala, C., Benjak, A., Cole, S.T., 2018. Essential Nucleoid Associated Protein mIHF (Rv1388) Controls Virulence and Housekeeping Genes in Mycobacterium tuberculosis. Sci. Rep. 8, 1-14. https://doi.org/10.1038/s41598-018-32340-2 
Mycobacterium tuberculosis hupB gene expression. Microbiology 160, 1637-1647. https://doi.org/10.1099/mic.0.079640-0

Pinson, V., Takahashi, M., Rouviere-Yaniv, J., 1999. Differential binding of the Escherichia coli $\mathrm{HU}$, homodimeric forms and heterodimeric form to linear, gapped and cruciform DNA. J Mol Biol 287, 485-497. https://doi.org/10.1006/jmbi.1999.2631

Schubert, O.T., Ludwig, C., Kogadeeva, M., Zimmermann, M., Rosenberger, G., Gengenbacher, M., Gillet, L.C.C., Collins, B.C.C., Röst, H.L., Kaufmann, S.H.E., Sauer, U., Aebersold, R., 2015. Absolute Proteome Composition and Dynamics during Dormancy and Resuscitation of Mycobacterium tuberculosis. Cell Host Microbe 18, 96-108. https://doi.org/10.1016/j.chom.2015.06.001

Serrano, P., Pedrini, B., Mohanty, B., Geralt, M., Herrmann, T., Wüthrich, K., 2012. The JUNIO protocol for automated protein structure determination by NMR in solution. J Biomol NMR 53, 341-354. https://doi.org/10.1007/s10858-012-9645-2

Song, D., Loparo, J.J., 2015. Building bridges within the bacterial chromosome. Trends Genet. 31, 164-173. https://doi.org/10.1016/j.tig.2015.01.003

Summers, E.L., Meindl, K., Usón, I., Mitra, A.K., Radjainia, M., Colangeli, R., Alland, D., Arcus, V.L., 2012. The structure of the oligomerization domain of Lsr2 from Mycobacterium tuberculosis reveals a mechanism for chromosome organization and protection. PLoS One 7, e38542. https://doi.org/10.1371/journal.pone.0038542

Swiercz, J.P., Nanji, T., Gloyd, M., Guarné, A., Elliot, M. a, 2013. A novel nucleoid-associated protein specific to the actinobacteria. Nucleic Acids Res. 41, 4171-84. https://doi.org/10.1093/nar/gkt095

Thomas A. Hall, 1999. BioEdit: a user-friendly biological sequence alignment editor and analysis program for Windows 95/98/NT. Nucleic Acids Symp. Ser. 41, 95-98. https://doi.org/10.1002/jps

Volk, J., Herrmann, T., Wüthrich, K., 2008. Automated sequence-specific protein NMR assignment using the memetic algorithm MATCH. J. Biomol. NMR 41, 127-138. https://doi.org/10.1007/s10858-008-9243-5 
WHO, 2016. Global Tuberculosis Report 2016. Cdc 2016 214. https://doi.org/ISBN 978924 1565394

Williamson, M.P., 2013. Using chemical shift perturbation to characterise ligand binding. Prog. Nucl. Magn. Reson. Spectrosc. 73, 1-16. https://doi.org/10.1016/j.pnmrs.2013.02.001

Zondervan, N.A., Van Dam, J.C.J., Schaap, P.J., Dos Santos, V.A.P.M., Suarez-Diez, M., 2018. Regulation of three virulence strategies of Mycobacterium tuberculosis: A success story. Int. J. Mol. Sci. 19, 9-12. https://doi.org/10.3390/ijms19020347

Zumla, A., Nahid, P., Cole, S.T., 2013. Advances in the development of new tuberculosis drugs and treatment regimens. Nat. Rev. Drug Discov. 12, 388-404. https://doi.org/10.1038/nrd4001 